\title{
Modes of $\mathrm{A} \beta$ toxicity in Alzheimer's disease
}

\author{
Jürgen Götz • Anne Eckert • Miriam Matamales • \\ Lars M. Ittner • Xin Liu
}

Received: 21 March 2011/Revised: 1 June 2011/Accepted: 6 June 2011/Published online: 25 June 2011

(c) The Author(s) 2011. This article is published with open access at Springerlink.com

\begin{abstract}
Alzheimer's disease (AD) is reaching epidemic proportions, yet a cure is not yet available. While the genetic causes of the rare familial inherited forms of $\mathrm{AD}$ are understood, the causes of the sporadic forms of the disease are not. Histopathologically, these two forms of AD are indistinguishable: they are characterized by amyloid- $\beta$ $(\mathrm{A} \beta)$ peptide-containing amyloid plaques and tau-containing neurofibrillary tangles. In this review we compare AD to frontotemporal dementia (FTD), a subset of which is characterized by tau deposition in the absence of overt plaques. A host of transgenic animal AD models have been established through the expression of human proteins with pathogenic mutations previously identified in familial AD and FTD. Determining how these mutant proteins cause disease in vivo should contribute to an understanding of the causes of the more frequent sporadic forms. We discuss the insight transgenic animal models have provided into $\mathrm{A} \beta$ and tau toxicity, also with regards to mitochondrial function and the crucial role tau plays in mediating $\mathrm{A} \beta$ toxicity. We also discuss the role of miRNAs in mediating the toxic effects of the $\mathrm{A} \beta$ peptide.
\end{abstract}

J. Götz $(\bowtie) \cdot$ M. Matamales $\cdot$ L. M. Ittner · X. Liu

Alzheimer's and Parkinson's Disease Laboratory, Brain and Mind Research Institute, University of Sydney, 100 Mallett St, Camperdown, NSW 2050, Australia

e-mail: juergen.goetz@sydney.edu.au

\section{A. Eckert}

Neurobiology Laboratory for Brain Aging and Mental Health, Psychiatric University Clinics, University of Basel, Basel, Switzerland
Keywords Alzheimer Amyloid .

Frontotemporal dementia · Fyn · miRNA - Mitochondria · Oligomer · Proteomic $\cdot$ Tau $\cdot$ Transgenic

\section{Introduction}

One of the major burdens associated with advanced age is dementia, a pathological condition defined as the significant loss of intellectual abilities-such as memory functions - that is severe enough to interfere with social or occupational functioning. The relentless neuronal degeneration that is associated with Alzheimer's disease (AD) and the more than two dozen related disorders affects a steadily increasing percentage of the population worldwide. More than 26 million people worldwide are currently living with $\mathrm{AD}$, a number that will quadruple to more than 106 million by 2050 unless effective treatments or a cure are found. Of all dementing disorders, $\mathrm{AD}$ is the most common form, comprising $50-70 \%$ of all reported cases. Frontotemporal dementia (FTD), in comparison, is less frequent, but may account for up to $50 \%$ of all dementia cases presenting before the age of 60 years [1]. At the present time, neither AD nor FTD can be cured although lifestyle choices, such as of diet and exercise, confer some form of protection [2].

\section{Neuropathological features of AD and FTD}

When in the years of 1992 and 1997, the 100-year-old histological slides of Alois Alzheimer's original cases were rediscovered in the basement of the Institute of Neuropathology of the University of Munich [3], they revealed what Alzheimer had described in his first case, Auguste D, 
as the key features of the disease named after him: the presence of overt neurofibrillary tangles (NFTs) and amyloid plaques. While Alzheimer was the first to describe NFTs [4], the credit of reporting amyloid plaques for the first time goes to Fischer and Redich [5]. Plaques and NFTs are the key histopathological hallmarks of AD (Fig. 1). The $\mathrm{AD}$ brain is further characterized by massive neuronal cell and synapse loss at specific predilection sites [6]. The major proteinaceous component of the plaques is a $40-42$ amino acid polypeptide amyloid- $\beta\left(\mathrm{A} \beta ;\left(\mathrm{A} \beta_{40}\right.\right.$ and $\left.\mathrm{A} \beta_{42}\right)$ that is derived by proteolytic cleavage from the larger amyloid precursor protein APP [7, 8]. The enzyme $\beta$-secretase generates the amino terminus of $\mathrm{A} \beta$, while $\gamma$-secretase cleavage at the carboxy-terminus dictates its length. $\mathrm{A} \beta_{40}$ is the most common species and $\mathrm{A} \beta_{42}$ the more fibrillogenic. $\beta$-Secretase activity has been attributed to a single protein, BACE 1 [9], whereas $\gamma$-secretase activity depends on four essential components, namely, presenilin, nicastrin, APH-1, and PEN-2, which together form a proteolytic complex [10]. $\alpha$-Secretase is the enzyme that is involved in the non-amyloidogenic pathway, by

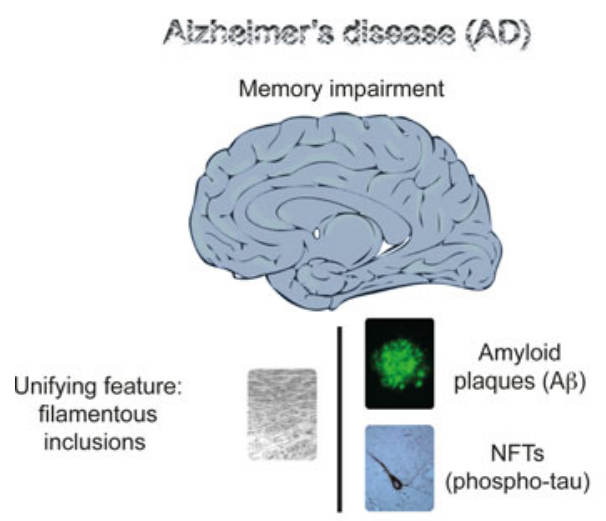

FAD: $\mid$ APP $(A \beta)$

PSEN1 (AB)

PSEN2 (A $\beta)$

Fig. 1 Histopathological and genetic features of Alzheimer's disease $(A D)$ and frontotemporal dementia (FTD). Memory impairment characterizes $\mathrm{AD}$ at a clinical level, and the presence of amyloid $(A \beta)$ plaques and phospho-tau-containing neurofibrillary tangles $(N F T s)$ in brain at a histopathological level. A unifying feature of the plaques and tangles is that their major proteinaceous components, $\mathrm{A} \beta$ and tau, respectively, are fibrillar. Plaques are scarce in FTD. The prominent feature in FTD is a behavioral impairment, with memory functions often being preserved until late in disease. Compared to $\mathrm{AD}, \mathrm{FTD}$ is a highly heterogeneous group of related dementias, as reflected both by the function of the mutated genes, by the proteins that are deposited as insoluble aggregates, and by the clinical syndromes, with language and behavioral variants known. A subset of FTD, known as frontotemporal lobar degeneration with tau deposits $($ FTLD $-T)$ or FTD with Parkinsonism linked to chromosome 17 cleaving APP within the $\mathrm{A} \beta$ domain and thus precluding $\mathrm{A} \beta$ formation [11].

The second histopathological hallmark of $\mathrm{AD}$ are the neurofibrillary lesions that are found in cell bodies and apical dendrites as NFTs, in distal dendrites as neuropil threads, and in the abnormal neurites that are associated with some plaques (neuritic plaques). NFTs are also abundant, in the absence of overt plaques, in over two dozen tauopathies that represent a significant subset of FTD [12]. The neurofibrillary lesions are mainly composed of highly phosphorylated, aggregated assemblies of the protein tau $[13,14]$. Tau belongs to the family of microtubule-associated proteins (MAPs) that includes MAP2. As neurons develop, tau segregates into axons, and MAP2 into dendrites [15]. In the axon, tau stabilizes the microtubules. Under pathological conditions tau dissociates from the microtubules, causing them to collapse, and tau starts accumulating in the somatodendritic compartment. The precise steps of this process are not fully understood. The established axonal localization of tau does not exclude the fact that under physiological conditions, this protein exerts
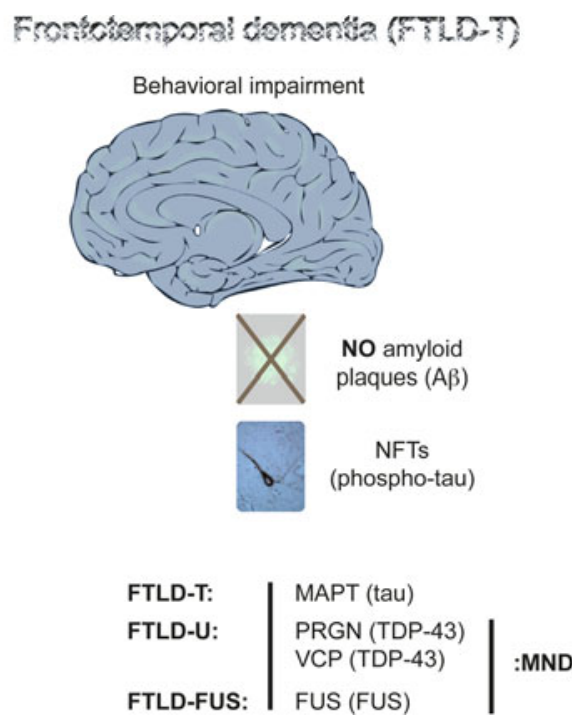

(FTDP-17), is characterized by tau inclusions. The first FTD mutations were identified in the tau-encoding MAPT gene causing FTLD-T. Mutations have been subsequently identified in the PGRN gene encoding progranulin, and in the $V C P$ gene encoding valosincontaining protein. TDP-43 is the deposited protein, and these deposits are shared with motor neuron disease $(M N D)$, also known as amyotrophic lateral sclerosis (ALS). Fused in sarcoma (FUS) is another pathological protein that has been identified in a small subset of patients with either ALS or a form of FTD. In familial AD (FAD), mutations have been identified in the $A P P$ gene encoding the amyloid precursor protein from which $\mathrm{A} \beta$ is derived by proteolytic cleavage, and in the genes encoding presenilin 1 and 2 (PSEN1 and PSEN2), which form part of the $\mathrm{A} \beta$ cleavage machinery. In $\mathrm{AD}$, no mutations have been identified in the tau-encoding MAPT gene 
important functions outside of the axon, such as in the dendrite, as we have recently shown [16].

Tau contains an unusually high number of putative phosphorylation sites (45 serines, 35 threonines, and 4 tyrosines), and for many of these, specific antibodies are available [17]. Under physiological conditions, there are on average 2-3 mol of phosphate per mol of tau, whereas under pathological conditions this ratio is increased to 7-8 mol [18]. This posttranslational modification has been termed 'hyperphosphorylation': some sites are phosphorylated to a higher degree in the diseased than in the healthy brain; others are de novo phosphorylated. Phosphorylation tends to dissociate tau from microtubules. Tau also undergoes a conformational change that is likely to assist in differential phosphorylation [19]. Both tau and $\mathrm{A} \beta$ undergo nucleation-dependent fibril formation [20]. In the course of this process, initially dispersed polypeptide chains slowly come together to form a diverse array of fibrillation nuclei that enable the rapid outgrowth into higher order assemblies, including fibrils [21-23]. Tau is generally perceived as a neuronal protein; however, in tauopathies such as progressive supranuclear palsy (PSP) or corticobasal degeneration (CBD), the protein forms aggregates in nonneuronal cells [24], emphasizing the important role of glia in neurodegenerative disease [25].

In $\mathrm{AD}$, the most severe neuropathological changes occur in the hippocampal formation, followed by the association cortices and subcortical structures, including the amygdala and the nucleus basalis of Meynert [26]. NFTs develop and spread in a predictable manner across the brain, providing the basis for distinguishing six stages of disease progression: the transentorhinal Braak stages I-II represent clinically silent cases; the limbic stages III-IV, incipient AD; the neocortical stages V-VI, fully developed AD. By using phosphorylation-dependent anti-tau antibodies, such as AT8, neuronal changes can be visualized well before the actual formation of NFTs $[27,28]$. In FTD, there is atrophy of the frontal and temporal cortex that is often asymmetrical.

\section{Genetic causes of AD and FTD}

What is causing AD is not understood, with the exception of the rare, familial (FAD) forms; the latter, however, account for less than $1 \%$ of all cases [29]. In FAD, autosomal dominant mutations have been identified in three genes: in APP itself, and in the presenilin 1- (PSEN1) and presenilin 2-encoding (PSEN2) genes (Fig. 1). In addition to the FAD genes, a series of susceptibility genes have been identified in sporadic AD (SAD); these include apolipoprotein $E(A P O E)$ as the most established risk gene [30] $C L U$ encoding clusterin, PICALM encoding the phosphatidylinositol-binding clathrin assembly protein, and $C R 1$ encoding the complement component $(3 \mathrm{~b} / 4 \mathrm{~b})$ receptor 1 [31-33]. Clinically and histopathologically, early-onset FAD cannot be discriminated from late-onset SAD [24].

Compared to AD, FTD is a highly heterogeneous group of related dementias, as reflected both by the function of the mutated genes, by the proteins that are deposited as insoluble aggregates, and by the clinical syndromes, with language and behavioral variants known [34]. The first FTD mutations were identified in FTDP-17 (FTD with Parkinsonism linked to chromosome 17) in the tau-encoding MAPT gene [35-37]. This subset of FTD, also known as FTLD-T (frontotemporal lobar degeneration with tau deposits) is characterized by tau inclusions (Fig. 1). There is also a subset of FTD that lacks tau aggregates but presents with an abundance of ubiquitin-positive lesions. The nature of the aggregating protein was not known until recently. This 'dementia lacking distinctive histology' (now termed FTLD-U or FTDU-17) is caused by loss-of-function mutations in the PGRN gene that encodes the pleiotropic protein progranulin, and in the $V C P$ gene that encodes valosin-containing protein $[38,39]$; the aggregating protein is TDP-43 (TAR DNA-binding protein 43), a highly conserved heteronuclear ribonucleoprotein (hnRNP) [40]. Fused in sarcoma (FUS) is another pathological protein that has been identified in a small subset of patients with either amyotrophic lateral sclerosis (ALS) or a form of FTD [41]. Finally, mutations in $C H M P 2 B$ that encodes chromatinmodifying protein $2 \mathrm{~B}$ cause FTD in the absence of either tau or TDP-43 inclusions [42]. For detailed information and an update on the genes and mutations in familial AD and FTD, we refer the reader to two websites-http://www.molgen. ua.ac.be/ADMutations and http://www.molgen.ua.ac.be/ FTDMutations-both of which are continually updated resources.

\section{Clinical features of AD and FTD}

The accurate differential diagnosis of AD and FTD remains a difficult yet important clinical issue, particularly with the advent of treatments that are designed to target the causes and/or consequences of specific types of dementia [43]. With the recent advent of positron emission tomography (PET) imaging, it has become possible to assess $\mathrm{A} \beta$ deposition longitudinally and explore its relationship with cognition and disease progression. For example, in one study that involved over 200 subjects and a 20-month clinical follow-up after $\left[{ }^{11} \mathrm{C}\right]$ Pittsburgh compound $\mathrm{B}(\mathrm{PiB})-$ PET and two additional follow-ups for up to 3 years with lower numbers of subjects, at baseline, $97 \%$ of AD, $69 \%$ of mild cognitive impairment (MCI), and $31 \%$ of healthy 
control (HC) subjects showed high $\mathrm{PiB}$ retention [44]. At the 20-month follow-up, small but significant increases in $\mathrm{PiB}$ standardized uptake value ratios were observed in the $\mathrm{AD}$ and MCI groups, as well as in the HCs with high PiB retention at baseline $(5.7,2.1$, and $1.5 \%$, respectively). There was a weak correlation between $\mathrm{PiB}$ increases and the decline in cognition when all groups were combined. Progression to AD occurred in $67 \%$ of MCI with high PiB versus $5 \%$ of those with low $\mathrm{PiB}$, but $20 \%$ of the low PiB MCI subjects progressed to other dementias. Of the high PiB HCs, 16\% developed MCI or AD within 20 months and $25 \%$ by 3 years. One low PiB HC developed MCI. Taken together, these results indicate that $\mathrm{A} \beta$ deposition increases slowly from cognitive normality to moderate severity AD. Extensive A $\beta$ deposition precedes cognitive impairment and is associated with a higher risk of cognitive decline in HCs and progression from MCI to AD over 1-2 years. Importantly, the cognitive decline is only weakly related to the change in $\mathrm{A} \beta$ plaque burden, suggesting that downstream factors have a more direct effect on symptom progression [44]. One of these down-stream factors may well be differences in protein levels of tau, with low levels conferring protection [45].

$\mathrm{AD}$ is characterized by deficits in memory, visuospatial ability, language, and executive function. While cognitive deficits have traditionally been emphasized in defining AD, there are a variety of neurobehavioral symptoms that are also commonly associated with the disease, including increased apathy, agitation, anxiety, and psychiatric symptoms, such as delusions or hallucination [46]. In contrast to AD, which is predominantly characterized by memory loss, FTD is mainly initiated by behavioral impairment (Fig. 1). The neurobehavioral symptoms include overeating, apathy or euphoria, disinhibition, depression, stereotyped behaviors, reduced empathy, and antisocial and aggressive behaviors. Patients with FTD also show a variety of cognitive problems, such as language and memory impairments, which are often coupled with a lack of insight into these changes [47]. In a significant subset of FTD, late Parkinsonism is found [12]. The diagnosis is based on the person's clinical presentation, the medical history and examination, neuropsychological assessments and, increasingly, brain imaging. However, due to its insidious and gradual onset, the diagnosis of FTD can be difficult. Furthermore, the behavioral symptoms, such as apathy or impulsive responding, that are associated with FTD can have a negative impact on cognitive performance, and patients may be quite often wrongly diagnosed with AD [48]. At present, AD and FTD can only be definitively diagnosed at autopsy. The average age of diagnosis of FTD is about 60 years, which is in the order of 10 years before the average $\mathrm{SAD}$ patient is diagnosed $[49,50]$.

\section{Animal models of AD and FTD}

To better understand the role of $\mathrm{A} \beta$ and tau in $\mathrm{AD}$ and related disorders, experimental animal models have been developed, in particular in mice, that reproduce the major aspects of the neuropathological characteristics of these diseases [11, 51]. Massive neuronal cell loss, however, has only been achieved for a small subset of mouse strains.

In 1995, Games and coworkers established the first $\mathrm{A} \beta$ plaque-forming mouse strain through expression of the disease-linked V717F mutant form of APP in the brain, under control of the platelet-derived growth factor minipromoter. These PDAPP mice showed many of the pathological features of $\mathrm{AD}$, including extensive deposition of extracellular amyloid- $\beta$ plaques, astrocytosis, and neuritic dystrophy [52]. Similar features were observed in the Tg2576 strain established by Hsiao and coworkers, by expressing the $\mathrm{APP}^{\mathrm{sw}}$ mutation inserted into a hamster prion protein cosmid vector [53]. The plaque-forming APP23 strain was established by expressing APP $^{\text {sw }}$ under the control of the neuronal mThy1.2 promoter [54, 55]. The common features of these strains is the development of amyloid plaques that are associated with memory impairment [11]. Subsequently, many other models have been developed with a pronounced plaque pathology, such as the TgCRND8 or the J20 mice $[56,57]$.

In the same year in which the first plaque-forming mice were established, the first tau transgenic mouse model was also generated, by expressing the longest human wild-type brain tau isoform, htau40, under control of the neuronal hThy1 promoter [58]. Despite the lack of an NFT pathology, the mice reproduced the somatodendritic localization of hyperphosphorylated tau in AD. They presented a pathology that is best described as an early 'pre-tangle' phenotype. A more pronounced tau phenotype was eventually achieved through the use of stronger promoters [59-62]. NFT formation, however, was only reproduced in mice in 1998, following the identification of pathogenic FTDP-17 mutations in the $M A P T$ gene, by targeting FTD mutant tau expression to both neuronal and glial cells [11]. Our group, for example, expressed two mutant forms of tau, G272V and P301L, in separate strains that both developed NFTs [63-67], while mice with pseudophosphorylated tau fail to develop NFTS [68]. The P301L tau-expressing pR5 mice showed a behavioral impairment in amygdala- and hippocampus-dependent tasks; aspects of the behavioral impairment could be correlated with the aggregation pattern of the transgene [67, 69-71]. K369I transgenic mice, on the other hand, model Parkinsonism in FTD, in parts owing to expression of the transgene in the substantia nigra, among other brain areas [72, 73]. 
Fig. 2 Modes of $\mathrm{A} \beta$ toxicity as illustrated for the signaling through the NMDA ( $N$-methyl D-aspartate) receptor (NMDAR). Tau is perceived as an 'axonal' protein, although a fraction of it is present in dendrites. Tau functions in targeting the kinase Fyn to this compartment. Fyn then phosphorylates the NMDAR subunit NR2B, thereby mediating complex formation of NMDARs with the post-synaptic density protein 95 (PSD95). The over-activation of the NMDAR complex (excitotoxicity) results in excessive nitric oxide $(N O)$ levels. This causes down-stream protein misfolding and aggregation, as well as mitochondrial fragmentation. The toxic signaling pathway also involves the release of mitochondrial cytochrome $\mathrm{c}$ $(C y t c)$ and the activation of down-stream caspases as well as the formation of reactive oxygen species $(R O S)$. The excitotoxicity complex mediates A $\beta$ 's toxic functions and subsequent neurodegeneration, a process that depends on the presence of tau. Inset:

Components of the mitochondrial respiratory chain itself are targets of $\mathrm{A} \beta$ and tau and, together, these toxic entities synergistically impair mitochondrial functions

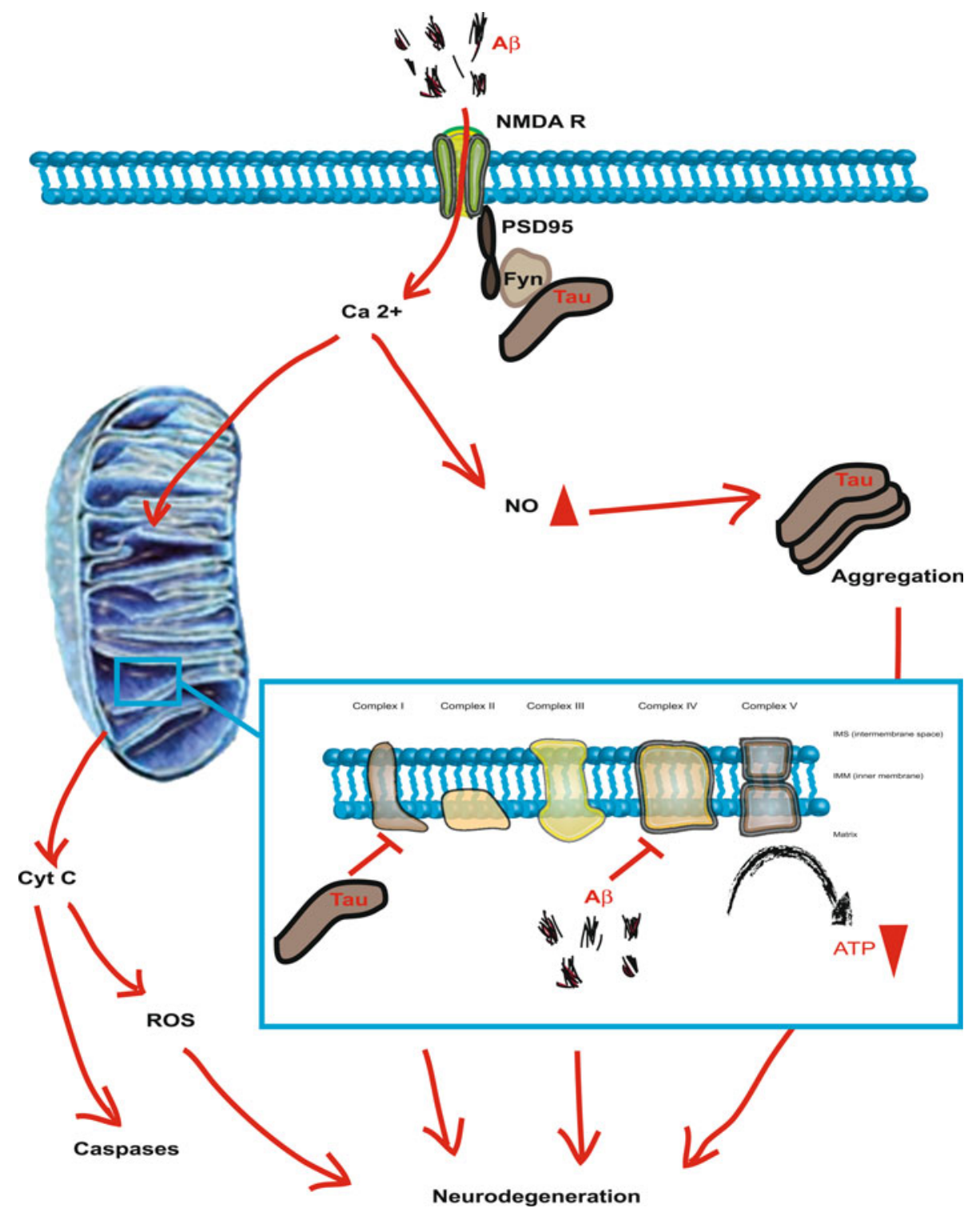

To achieve a more complete model of $\mathrm{AD}$, the plaque and NFT pathology has been combined in 3xtg-AD mice that express $\mathrm{APP}^{\mathrm{sw}}$ and P301L-tau expression on a mutant $\mathrm{PS}^{\mathrm{M} 146 \mathrm{~V}}$ knock-in background [74, 75]. These mice have been used extensively to dissect pathogenic mechanisms and more recently for gene therapeutic approaches [76]. Remarkably, cognitive function is improved without altering $\mathrm{A} \beta$ or tau pathology. Instead, the mechanism underlying the improved cognition involves a robust enhancement of hippocampal synaptic density, mediated by brain-derived neurotrophic factor (BDNF). Another model with combined pathologies addresses the role of tau phosphorylation at the pathogenic epitope S422 [77]. These ${ }^{\text {triple }} \mathrm{AD}$ mice have been used by us to assess the effects of $\mathrm{A} \beta$ and tau on mitochondrial functions (Fig. 2a) [78].

\section{$A \beta$ and down-stream signaling}

The amyloid cascade hypothesis claims, in simplistic terms, that there is a pathogenic degenerative cascade in $\mathrm{AD}$, with $\mathrm{A} \beta$ being upstream of tau [79]. To address the interaction of $\mathrm{A} \beta$ and tau [80], $\mathrm{A} \beta$ plaque-forming $\mathrm{Tg} 2576$ mice were crossed with NFT-forming P301L tau-transgenic JNPL3 mice [65, 81]; also, P301L tau transgenic pR5 mice were intracerebrally injected with fibrillar preparations of $\mathrm{A} \beta_{42}$. Both strategies caused an increased tau phosphorylation at pathological epitopes and increased NFT formation, thereby establishing a link between $\mathrm{A} \beta$ and tau in vivo $[65,81]$. These findings have been reproduced in vitro [82, 83]. Similarly, NFT formation was aggravated by infusing brain extracts of aged plaque-forming APP23 mice intracerebrally in $\mathrm{P} 301 \mathrm{~L}$ tau transgenic mice or by 
crossing $\mathrm{A} \beta$ plaque-forming APP23 and P301L tau transgenic mice [84]. Together, these studies established that $\mathrm{A} \beta$ exaggerates a pre-existing tau pathology supporting, at least in part, the amyloid cascade hypothesis in mice. They proved an essential role for $\mathrm{A} \beta$ in disease.

However, there is also an important role for tau. When hippocampal neurons from tau knockout and transgenic as well as wild-type control mice were cultured in the presence of $\mathrm{A} \beta$, it was found that the knockout neurons were resistant to $\mathrm{A} \beta$ toxicity, while those from tau transgenic mice were more susceptible [85]. In a next step towards showing an essential role for tau in mediating $\mathrm{A} \beta$ toxicity, Mucke and colleagues crossed plaque-forming APP transgenic mice onto hetero- and homozygous tau knockout backgrounds [86]. They found that this prevented the memory impairment that characterizes the APP mutant mice and, importantly (and somewhat surprisingly), that this improvement was achieved without any changes to $\mathrm{A} \beta$ levels or $\mathrm{A} \beta$ plaque load. Tau reduction also protected against pentylenetetrazole (PTZ)-mediated excitotoxicity, as shown by a reduced seizure severity and increased latency. Excitotoxicity describes a signaling cascade that is induced by the over-activation of the $N$-methyl-D-aspartate (NMDA) receptor (NMDAR), resulting in neuronal damage and death due to the generation of excessive nitric oxide (NO) (Fig. 2). This process has been implicated as one patho-mechanism underlying $\mathrm{A} \beta$-mediated neurodegeneration in $\mathrm{AD}$, despite a lack of evidence for a direct binding of $\mathrm{A} \beta$ to NMDARs $[87,88]$. Toxicity mediated by any particular receptor may not necessarily involve the direct binding of $\mathrm{A} \beta$, but it could be due to an indirect modulation of receptor properties, possibly through membrane association. This mechanism may explain why $\mathrm{A} \beta$ has been reported to bind to distinct receptors under certain conditions and not to others depending on the experimental design [89, 90]. Results from recent studies suggest that excessive NO can mediate excitotoxicity in part by triggering down-stream protein misfolding and aggregation, as well as mitochondrial fragmentation. S-Nitrosylation, or covalent reaction of $\mathrm{NO}$ with specific protein thiol groups, represents a convergent signal pathway contributing to NOinduced protein misfolding and aggregation, as well as mitochondrial fragmentation through A $\beta$-related $S$-nitrosylation of proteins, such as dynamin-related protein-1 (Drp1) [91]. The toxic signaling pathway also involves the release of mitochondrial cytochrome $\mathrm{c}$ and the activation of down-stream caspases [92, 93]. Excessive NMDAR activation thus precipitates the neuronal degenerative process, in part by mitochondrial dysfunction [94].

Coming back to the interaction of tau and $\mathrm{A} \beta$, the important question arises how tau in fact mediates $\mathrm{A} \beta$ toxicity and why its removal prevents it? In order to decipher the underlying mechanisms, we generated a mouse strain that expresses the projection domain of tau, while lacking the microtubule-binding domain [16]. When these so-called $\Delta$ tau mice were crossed with $\mathrm{A} \beta$ plaqueforming APP23 mice, the high susceptibility to excitotoxicity that characterizes the APP23 strain was rescued; also rescued was early mortality. In addition, the memory phenotype of these mice improved; and again, the rescue occurred in the absence of any changes to APP mRNA levels, or A $\beta$ plaque load. Similarly, crossing the APP23 mice onto a second tau knockout background confirmed the previous findings of Mucke and colleagues on the protective role of not having tau $[16,86]$. When we analyzed the subcellular localization of the projection domain tau in $\Delta$ tau mice, we found that it accumulated in the soma, while it was excluded from the dendrite. What links tau and the NMDAR is the non-receptor tyrosine kinase Fyn, establishing a toxic triad [95]. We found by enhanced immunohistochemistry that already under physiological conditions a fraction of tau is present in the dendrites (Fig. 2) [16]. It functions in targeting the kinase Fyn to the dendrite where the enzyme phosphorylates the NMDAR subunit NR2B, thereby mediating complex formation of the NMDAR with the post-synaptic density protein 95 (PSD95) [96]. In the presence of $\Delta$ tau, this truncated version of tau competes with endogenous (fulllength) tau in the binding to Fyn, trapping it in the soma and preventing it from entering the dendrites. Therefore, Fyn is not available for phosphorylation of NR2B's Y1472 and hence, the excitotoxic signaling complex cannot be formed. Likewise, in tau knockout mice, tau is not available in the first place, and Fyn is thus not targeted to the dendrite. While excitotoxic signaling is impaired in $\Delta$ tau over-expressing or tau knockout mice, we found no significant changes in synaptic NMDAR expression levels and NMDA currents [16]. In addition to the genetic approach, we tested the pharmacological uncoupling of the NMDAR/ PSD95 complex in APP23 mice by delivering a small peptide, Tat-NR2B9c, composed of the carboxy-terminal amino acids of NR2b (including Y1472) fused to a HIV1Tat peptide [97], using an osmotic pump. This approach permanently protected the APP 23 mice from experimentally induced seizures and memory impairment and extended their lifespan to that of wild-type mice. However, crossing the APP23 mice with P301L tau mutant pR5 mice that are characterized by tau accumulation in the soma and, importantly, in the dendrites, caused a dramatic effect in that none of the mice survived beyond the age of 4 months [16]. Tau reduction has subsequently been shown to further prevent the $\mathrm{A} \beta$-induced defects in the axonal transport of mitochondria [98].

Together, these findings lead us to propose the 'tau axis hypothesis' [45] which postulates that progressively increasing levels of dendritic tau make neurons more 
vulnerable to $\mathrm{A} \beta$ : at the onset of $\mathrm{AD}, \mathrm{A} \beta$ levels in the brain increase. The presence of tau at low levels in the dendrites (low compared to levels in the axon) renders, to some degree, the dendrites (and their spines) vulnerable to postsynaptic $\mathrm{A} \beta$ toxicity (Fig. $2 \mathrm{~b}$ ). With disease progressing, tau becomes increasingly phosphorylated (a process driven in part by $\mathrm{A} \beta$ ), and tau accumulates in the soma and the dendrites. In fully manifested AD, levels of tau in the dendrite (dendritic spine) are high, and this is associated with an increased neuronal vulnerability to $\mathrm{A} \beta$ toxicity. As $\mathrm{A} \beta$ increases further, it exacerbates tau's phosphorylation and somatodendritic accumulation, thereby hypersensitizing the synapses to $\mathrm{A} \beta$ 's toxicity. Ultimately, this process results in the loss of synapses and causes neuronal degeneration [6]. There is an increasing understanding that in $\mathrm{AD}$ the neuronal network is disturbed and as the disease is initiated at one particular site, it is spreading through the brain via synaptic connections. This concept has been addressed in mice by targeting transgene expression to distinct subregions of the brain, such as the entorhinal cortex (EC) [99]. In this brain area, NFT formation was found to be initiated in AD. Transgenic overexpression of $\mathrm{APP} / \mathrm{A} \beta$ in the $\mathrm{EC}$ elicited abnormalities in synaptic functions and activity-related molecules in the hippocampal dentate gyrus and CA1 regions, as well as epileptiform activity in the parietal cortex. Soluble $\mathrm{A} \beta$ was observed in the dentate gyrus, and $\mathrm{A} \beta$ deposits in the hippocampus were localized to terminal fields of the perforant pathway. Thus, the authors concluded that APP/A $\beta$ expression in EC neurons causes transsynaptic deficits that may initiate a cortico-hippocampal network dysfunction in both mouse models and human patients with $\mathrm{AD}$ [99].

What is the identity of the $\mathrm{A} \beta$ receptor(s) and what are the down-stream effectors of its toxicity? At present it is not understood whether $\mathrm{A} \beta$ acts via a receptor or whether membrane binding alone is sufficient [100]. If $\mathrm{A} \beta$ acts via a receptor, this receptor may have specificity for $\mathrm{A} \beta$ or it may bind proteins or peptides with shared amyloid properties. Work on primary cortical and hippocampal cultures treated with the amyloidogenic peptides $\mathrm{A} \beta$ and human amylin, respectively, indicates that the latter may be the case, as rat amylin, which is not amyloidogenic, turns out not to be toxic, while both $\mathrm{A} \beta$ and human amylin are [101]. These findings underscore commonalities between $\mathrm{AD}$ and type 2 diabetes mellitus [102]. Membrane interaction of $\mathrm{A} \beta$ can occur via its hydrophobic carboxy-terminal domain $[103,104]$ or by electrostatic interactions mediated by the charged amino acids in the amino-terminal domain [105]. A $\beta$ may bind to the cell membrane to form channels or pores that disrupt ion homeostasis, hence leading to neuronal dysfunction [103, 106-109]. As several molecules associated with disease, such as the Prion protein, the
British peptide, or human amylin, can form soluble oligomers, bind to membranes, and subsequently disrupt ion homeostasis, this may be an inherent property of amyloidogenic proteins or peptides [110].

As discussed above, toxicity mediated by the NMDAR may not necessarily involve direct binding of $\mathrm{A} \beta$, rather it could be due to an indirect modulation of receptor properties, possibly through membrane association [89, 90]. Normal NMDAR signaling is a multi-step process, with contributions by the fast acting nuclear $\mathrm{Ca}^{2+} /$ calmodulindependent protein $(\mathrm{CaM})$ kinase pathway and the slower acting, longer lasting Ras-extracellular signal-regulated kinase 1/2 (ERK1/2) pathway, which translocate to the nucleus and ultimately result in activation of the transcription factor CREB [111]. Too much calcium influx via the NMDAR, such as under excitototoxic conditions, leads to neuronal death. While a long-standing view is that neuronal responses to NMDAR activity follow a bellshaped curve, in which both too much and too little response is potentially harmful, this view has been recently revisited in that the location of the NMDAR may influence whether its activation is coupled to pro-death or pro-survival signals [111].

$\mathrm{A} \beta$ may induce synaptic and neuronal degeneration via a plethora of pathways [112]. A $\beta$ 's anti-LTP (long-term potentiation) activity can be modulated by antagonists of the p38 MAP kinase [113] and the Jun $\mathrm{NH}_{2}$-terminal kinase (JNK) pathways [114], both of which have been implicated in the hyperphosphorylation of tau $[115,116]$. In one study, inhibitors of $\mathrm{p} 38$, JNK, GSK- $3 \beta$, and phosphatidylinositol 3-kinase showed either no or only minor inhibition of $\mathrm{A} \beta$ oligomer-mediated cell death in mouse hippocampal slices, but inhibitors of MAPK kinase kinase (MAPKKK), which is upstream of the extracellular ERKs, significantly inhibited $\mathrm{A} \beta$-mediated neuronal death [117]. Another interesting kinase is Fyn, as it links $\mathrm{A} \beta$ and tau [45]. Not only is Fyn an interaction partner of tau [118], it also phosphorylates tau at Y18 [119]. Fyn is necessary for the toxicity of $\mathrm{A} \beta$-derived diffusible ligands (ADDL, an oligomeric form of $\mathrm{A} \beta$ ) as Fyn knockout neurons are resistant to ADDL-mediated neuronal cell death [120]. Moreover, when crossed with APP transgenic mice, Fyn knockout mice display reduced synaptotoxicity without affecting aberrant sprouting [121, 122]. Fyn has a role in modulating synaptic activity and plasticity through its phosphorylation of NMDAR [123]. While tau reduction prevents cognitive deficits in $\mathrm{A} \beta$-forming APP transgenic mice, Fyn overexpression exacerbates them.

Using electroencephalography (EEG) to examine network effects, researchers have recorded whole-cell currents in acute hippocampal slices from APP mice in the presence or absence of tau. APP mice with tau had increased spontaneous and evoked excitatory currents, reduced 
inhibitory currents, and NMDAR dysfunction. Tau reduction increased inhibitory currents and normalized the excitation/inhibition balance and NMDAR-mediated currents in the APP mutant mice [124]. These findings are consistent with the fact that $\mathrm{A} \beta$ oligomers alter the transport of NMDAR by promoting its endocytosis, resulting in decreased receptor activity both in vitro and in the APP transgenic mice [125]. Work on neuronal and astrocyte cultures further suggests that $\mathrm{A} \beta$ causes $\mathrm{Ca}^{2+}$ dependent oxidative stress by activating an astrocytic NADPH oxidase, with neuronal death following through a failure of antioxidant support [126]. Together, these results suggest a fine-balanced network of molecular interactions [100].

\section{Neurotoxicity of different $A \beta$ species}

Alzheimer's disease is believed to be a disease of the synapses and has hence been termed a 'synaptic failure' [6]. While $\mathrm{A} \beta$ can kill neurons, synaptotoxicity may be more relevant for the earlier stages of $\mathrm{AD}$ that are best characterized by synaptic loss rather than neuronal death. Loss of synaptic terminals or dendritic spines could cause the associated decline in cognitive functions that characterizes $\mathrm{AD}$. Whether the neurotoxic and synaptotoxic actions of $\mathrm{A} \beta$ are separate activities or whether they share common mechanisms is not known [100].

The interpretation of $\mathrm{A} \beta$ toxicity studies is complicated by the fact that different preparations are being used, such as $\mathrm{A} \beta 42$ versus the less amyloidogenic $\mathrm{A} \beta 40$ versus the shorter, cheaper $A \beta 25-35$ version, aged versus fresh preparations, monomers versus oligomers versus fibrils; on top of that, different concentrations, incubation times, and cellular system add additional levels of complexity [127, 128]. For example, it was found early on that while $\mathrm{A} \beta$ peptide added at micromolar concentrations to primary neuronal cultures induces cell death [129], low, subnanomolar concentrations are neurotrophic, arguing in favor of a physiological function of $\mathrm{A} \beta$ [129]. When $\mathrm{A} \beta$ aggregation was induced, this aggregation increased the neurotoxic activity of the $\mathrm{A} \beta$ peptide, suggesting that the toxic species are associated with the formation of fibrils [130-132]. At present, however, major research efforts of many groups concentrate on non-fibrillar soluble $\mathrm{A} \beta$ as the major toxic species in AD [120,133-135]. These have been given different names, including ADDLs [120], globulomers [136], and the dodecameric $\mathrm{A} \beta$ species $\mathrm{A} \beta * 56$ [137]. Recent structural analysis has revealed that pentameric and hexameric oligomers may be the building blocks of the more toxic decameric and dodecameric complexes [138]. To assist in identifying the different $\mathrm{A} \beta$ species, conformational antibodies have been developed that not only stabilize the $\mathrm{A} \beta$ protofibrils but also prevent mature amyloid fibril formation [135, 139].

$\mathrm{A} \beta$ can inhibit long-term potentiation (LTP), a model system for synaptic strengthening and memory $[120,133$, 140-142]. When cell medium containing abundant $\mathrm{A} \beta$ monomers and putative oligomers-but not amyloid fibrils-was microinjected into rat brain, this markedly inhibited hippocampal LTP [133]. Immunodepletion of all $\mathrm{A} \beta$ species from the medium completely abrogated this effect. Pretreatment of the medium with insulin-degrading enzyme (IDE), which degrades $\mathrm{A} \beta$ monomers but not oligomers, did not prevent the inhibition of LTP, indicating a crucial role for $\mathrm{A} \beta$ oligomers. These were shown to disrupt synaptic plasticity in vivo at concentrations found in the human brain and cerebrospinal fluid, in the absence of monomeric or fibrillar amyloid. When cells were treated with $\gamma$-secretase inhibitors at doses which prevented oligomer formation but allowed appreciable monomer production, LTP was not longer inhibited, indicating that synaptotoxic $\mathrm{A} \beta$ oligomers can be targeted therapeutically $[133,143]$. Oligomers caused a tenfold greater toxicity in Neuro-2A cells than in fibrils [144]. However, whereas LTP seems to be inhibited by oligomeric $\mathrm{A} \beta$ only and not by fibrillar $\mathrm{A} \beta$, in a different experimental paradigm, the two species seem to have both toxic, yet diverse effects [145]. Using rat astrocyte cultures, oligomeric A $\beta 42$ was shown to induce initial high levels of the pro-inflammatory molecule interleukin (IL)- $1 \beta$ that decreased over time, whereas fibrillar $\mathrm{A} \beta$ caused increased levels over time [145]. With respect to mitochondrial functions, we observed that fibrillar and oligomeric species demonstrated a very similar degree of toxicity (see below). It has been suggested that the neurotoxic activity of oligomers is associated with dimeric and trimeric species [133, 142] and, in a recent study, $\mathrm{A} \beta$ dimers were found to be the most abundant form of soluble oligomer detectable in the human brain [146]. They were isolated from the cortices of typical AD subjects, at subnanomolar concentrations, they first induced tau hyperphosphorylation in hippocampal neurons, subsequently disrupting the microtubule cytoskeleton, and they caused neuritic degeneration-all in the absence of amyloid fibrils.

The relative contribution of the two forms of $\mathrm{A} \beta-\mathrm{A} \beta 40$ and $\mathrm{A} \beta 42$ - to disease is a matter of debate. One of the major puzzles in the AD field is that a difference of just two residues between $\mathrm{A} \beta 40$ and $\mathrm{A} \beta 42$ markedly changes toxicity and aggregation properties. A structural study showed that the hydrophobic carboxy-terminal residues in A $\beta 42$ stabilize the neurotoxic low-order oligomers in a non- $\beta$-sheet secondary structure and that the conversion to protofibrils and fibrils having $\beta$-sheet secondary structure reduces toxicity [138]. In Drosophila, $\mathrm{A} \beta 42$ expression causes the formation of diffuse amyloid deposits, 
age-dependent learning deficits, and neurodegeneration. A $\beta 40$ causes similar learning deficits without aggregation and neurodegeneration [147]. On the other hand, rational mutagenesis applied to the $\mathrm{A} \beta 42$ peptide confirmed that the rate of aggregate formation in vitro is linked to brain toxicity [148]. Furthermore, flies expressing wild-type or E22G A $\beta 42$ had a median survival of 24 and 8 days, respectively, whereas $\mathrm{A} \beta 40$-expressing flies had a median survival of 30 days, indicating that $\mathrm{A} \beta 40$ may be non-toxic, and possibly protective [147]. This possibility is supported by nuclear magnetic resonance (NMR) studies which revealed that $\mathrm{A} \beta_{40}$ prevents $\mathrm{A} \beta_{42}$ from aggregating in vitro [149]. Thus, this aspect of toxicity and the relative role of monomeric, oligomeric, and fibrillar species are far from being resolved.

\section{A $\beta$-binding proteins and mitochondrial targets}

A number of $\mathrm{A} \beta$-binding proteins have been identified on the outside of the plasma membrane of neurons and glial cells that are limited to dealing with a highly sticky peptide, such as $\mathrm{A} \beta 42$. These proteins include the $\alpha 7$-nicotinic acetylcholine receptor, the receptor for advanced glycosylation end-products (RAGE), APP itself, NMDAR, the P75 neurotrophin receptor (P75NTR), CD36, and lowdensity lipoprotein receptor-related protein (LRP) members [150]. LRP, apoE, and the serum protein $\alpha 2$-macroglobulin $(\alpha 2 \mathrm{M})$ probably modulate $\mathrm{A} \beta$ toxicity via clearance of apoE: $\mathrm{A} \beta$ and $\alpha 2 \mathrm{M}: \mathrm{A} \beta$ complexes or $\mathrm{A} \beta$ alone from the brain and hence reduce $\mathrm{A} \beta$ levels $[151,152]$. Interestingly, in a study involving metabolic labeling, $\mathrm{A} \beta$ clearance rates were found to be relatively impaired in the central nervous system (CNS) of AD patients compared with controls, while production was unaffected [153]. Specifically, lateonset $\mathrm{AD}$ was associated with a $30 \%$ impaired clearance of both $\mathrm{A} \beta 42$ and $\mathrm{A} \beta 40$, indicating that clearance mechanisms may be critically important in the development of $\mathrm{AD}$. Estimates based on a $30 \%$ decrease in $\mathrm{A} \beta$ clearance rates suggest that the $\mathrm{AD}$ brain accumulates $\mathrm{A} \beta$ over a period of about 10 years. The impaired clearance of both $\mathrm{A} \beta 40$ and $\mathrm{A} \beta 42$ is consistent with prior findings of the deposition of both $\mathrm{A} \beta 40$ and $\mathrm{A} \beta 42$ in parenchymal amyloid plaques and the substantial deposition of $\mathrm{A} \beta 40$ in cerebral amyloid angiopathy in about $80 \%$ of cases of $\mathrm{AD}$ [154].

P75NTR can bind a variety of $\mathrm{A} \beta$ oligomeric species and modulate $\mathrm{A} \beta$ toxicity in a cell type- and $\mathrm{P} 75$ isoformdependent manner $[155,156]$. Full-length P75NTR blocks toxicity of both fibrillar and non-fibrillar $\mathrm{A} \beta$ preparations in primary neuronal cultures [157], but promotes toxicity of fibrillar $\mathrm{A} \beta$ in neuroblastoma cells [158]. The binding of $\mathrm{A} \beta$ oligomers to neurons can be blocked with an anti-
NMDAR antibody and, as a consequence, reactive oxygen species (ROS) stimulation in hippocampal cultures is reduced [159]. These results indicate different modes of toxicity in different cell types.

There is an increasing amount of data being published on intracellular sites of $\mathrm{A} \beta$ production and targeting, including intracellular organelles, such as mitochondria [160-164], whose function it impairs [165-169]. When we analyzed the total brain proteome of P301L tau transgenic pR5 and wild-type mice, we discovered that it consisted mainly of metabolically related proteins, including mitochondrial respiratory chain complex components, antioxidant enzymes, and synaptic proteins, that were modified. This deregulation could be functionally validated in the pR5 mice as mitochondrial dysfunction, and the reduction in mitochondrial complex $\mathrm{V}$ levels was confirmed in human P301L FTDP-17 brains [166]. In one study, we found that P301L tau mitochondria displayed an increased vulnerability towards fibrillar $\mathrm{A} \beta 42$ compared to control mitochondria, suggesting a synergistic action of tau and $\mathrm{A} \beta$ pathology on the mitochondria [166]. In a followup study we investigated the toxicity of oligomeric $\mathrm{A} \beta$ species [127, 128]. Interestingly, in cortical pR5 brain cells, both oligomeric and fibrillar-but not monomericA $\beta 42$ caused a decreased mitochondrial membrane potential. This was not observed with cerebellar preparations, indicating selective vulnerability of cortical neurons [167]. We also measured reductions in state 3 respiration, the respiratory control ratio, and uncoupled respiration when P301L tau mitochondria were incubated with either oligomeric or fibrillar preparations of $\mathrm{A} \beta 42$. We found that aging specifically increased the sensitivity of mitochondria to oligomeric $\mathrm{A} \beta 42$ damage, indicating that while oligomeric and fibrillar $\mathrm{A} \beta 42$ are both toxic, they exert different degrees of toxicity in mitochondria from older animals [167]. When we performed a comparative, quantitative iTRAQ proteomic analysis of single-transgenic pR5, double-transgenic APP/PS2 mutant, and triple $\mathrm{AD}$ (pR5/APP/ PS2) mice, as well as of wild-type controls, we found that one-third of the deregulated proteins were mitochondrial. Notably, deregulation of complex I was tau dependent, while deregulation of complex IV was $\mathrm{A} \beta$ dependent, both at the protein and activity levels. Synergistic effects of $\mathrm{A} \beta$ and tau were evident in 8-month-old ${ }^{\text {triple }} \mathrm{AD}$ mice as only they showed a reduction of the mitochondrial membrane potential at this early age. At the age of 12 months, the strongest defects on the oxidative phosphorylation system, the synthesis of ATP, and ROS levels were exhibited in the ${ }^{\text {triple }} \mathrm{AD}$ mice, again emphasizing synergistic, age-associated effects of $\mathrm{A} \beta$ and tau in perishing mitochondria [78]. Synergistic effects were also found by us in the neuroblastoma cell system in promoting aberrant cell cycle reentry [170]. 
Mitochondrial dysfunction has been linked to full-length and carboxy-terminally truncated APP, which was shown to accumulate exclusively in the protein import channels of mitochondria of human $\mathrm{AD}$, but not age-matched control brains [163]. Similarly, the accumulation of full-length APP in the mitochondrial compartment in a transmembrane-arrested form, but not lacking the acidic domain, was shown to cause mitochondrial dysfunction and impair energy metabolism [171]. A $\beta$ can disrupt mitochondrial cytochrome $c$ oxidase activity $[161,172]$ in a sequenceand conformer-dependent manner [161]. The $\mathrm{A} \beta$ binding protein alcohol dehydrogenase (ABAD, also known as ERAB) is a short-chain alcohol dehydrogenase that binds to $\mathrm{A} \beta$ in the mitochondrial matrix. $\mathrm{ABAD}$ can bind to oligomeric $\mathrm{A} \beta 42$ present in the cortical mitochondria of APP transgenic mice [173]. This interaction promotes leakage of ROS, mitochondrial dysfunction, and cell death-potentially underlying the mechanism of $\mathrm{A} \beta$-induced mitochondrial toxicity [160]. The results of protease sensitivity assays suggest that $\mathrm{A} \beta$ indeed gains access to the mitochondrial matrix rather than being simply adsorbed to the external mitochondrial surface [162]. The interaction between $\mathrm{A} \beta$ and mitochondria may explain how $\mathrm{A} \beta$ induces apoptosis and caspase activation [160, 174, 175]. In general, intracellullar $\mathrm{A} \beta$ may be derived either from internalized extracellular $\mathrm{A} \beta$ or from intracellularly generated $\mathrm{A} \beta$ [176-178]. As it stands, the putative existence of intracellular $\mathrm{A} \beta$ adds a further level of complexity to the mechanism of $\mathrm{A} \beta$ toxicity, obtaining direct access to organelles that are vital for the function and viability of neurons [179].

\section{$A \beta$, altered gene expression and miRNA deregulation}

The last years have seen vast improvements in the methods available for functional genomics studies. The effects of $\mathrm{A} \beta$ on the proteome and transcriptome can be assessed with increasingly smaller sample sizes and a higher sensitivity, and these methods have been applied successfully to $\mathrm{AD}$ and its model systems [180, 181]. Previously, we and others identified deregulated genes and proteins either in human AD tissue itself, or in tissue culture systems and animal models [182-184]. This approach not only identified deregulated genes and proteins but also pathogenic mechanisms, such as mitochondrial dysfunction, impaired unfolded protein responses, and changes in microRNA (miRNA) expression [185]. MicroRNAs (miRNAs) add another level of complexity to gene regulation. While initially identified for their roles in development and cellular identity, the role of miRNAs in human neurodegenerative disease has been increasingly acknowledged in more recent times [186-188]. miRNAs are evolutionarily conserved non-coding RNAs that are approximately 22 nucleotides and which negatively regulate gene expression in a sequence-specific manner [189, 190]. Changes in miRNA profiles have been reported for postmortem human AD brain tissue, where they include miRNAs that regulate genes such as $A P P$ itself or $B A C E 1$, which encodes the $\beta$-secretase involved in APP processing and $\mathrm{A} \beta$ formation [191-194]. Although the role of genes such as APP and $P S E N$ in familial AD is firmly established, little is known about the molecular mechanisms affecting $\mathrm{A} \beta$ generation in sporadic $\mathrm{AD}$. A deficiency in $\mathrm{A} \beta$ clearance is a possibility, as discussed above, but an increased expression of proteins such as APP or BACE1 may also be associated with the disease: a study of miRNA expression profiles in sporadic AD patients revealed that several miRNAs potentially involved in the regulation of APP and BACE1 expression appear to be decreased in the diseased brain. Of these, miR-29a, $-29 b-1$, and -9 can regulate BACE1 expression in vitro. The miR-29a/b-1 cluster was significantly (and AD-specific) decreased in $\mathrm{AD}$ patients displaying abnormally high BACE1 protein. Similar correlations between the expression of this cluster and BACE1 were found during brain development and in primary neuronal cultures. These results suggest that the loss of specific miRNAs can contribute to increased BACE1 and $\mathrm{A} \beta$ levels in sporadic $\mathrm{AD}$ [192]. In a comparison of human brain tissue to $\mathrm{A} \beta$-treated primary neuronal cultures or brain tissue derived from $\mathrm{A} \beta$-depositing APP mutant APP23 transgenic mice, we found a remarkable overlap in deregulated, mostly down-regulated miRNAs [185]. The down-regulation of approximately $50 \%$ of the miRNAs tested in response to $\mathrm{A} \beta$ was also observed, including down-regulation of miR-9 and 181c, which are also downregulated in human AD brain tissue [192, 195, 196]. Whether changes in miRNA profiles are specific for sporadic $\mathrm{AD}$, or whether they are a cause or a consequence of the disease process, remains to be investigated: the interesting opportunity that is offered, however, is that miRNAs, similar to protein markers, can be used for diagnostic purposes [192], as is the case for cancer patients [197].

\section{Conclusions}

What can be expected in the forthcoming years? Some of the current therapeutic trials targeting $\mathrm{A} \beta$ may come to fruition [11]. The mode of $\mathrm{A} \beta$ uptake and/or binding by neurons and other cell types will be elucidated and interacting proteins, both under physiological and pathologic conditions, will be identified. With the advent of new tools, it will likely become easier to discriminate $\mathrm{A} \beta$ conformations and hence allow the role of specific conformers in 
toxicity to be defined [139]. Moreover, the role that tau plays in mediating $\mathrm{A} \beta$ toxicity in disease will assist in the development of treatment strategies for $\mathrm{AD}$ and related disorders [45].

Acknowledgments This work has been supported by the University of Sydney, the National Health \& Medical Research Council (NHMRC), the Australian Research Council (ARC), and the J.O. \& J.R. Wicking Trust. Postgraduate scholarship support has been provided by the Wenkart Foundation, GlaxoSmithKline and Alzheimer's Australia. M. M is supported by an EMBO Long-Term Fellowship (ALTF 1228-2010).

Open Access This article is distributed under the terms of the Creative Commons Attribution Noncommercial License which permits any noncommercial use, distribution, and reproduction in any medium, provided the original author(s) and source are credited.

\section{References}

1. Graff-Radford NR, Woodruff BK (2007) Frontotemporal dementia. Semin Neurol 27:48-57

2. Daffner KR (2010) Promoting successful cognitive aging: a comprehensive review. J Alzheimers Dis 19:1101-1122

3. Graeber MB (1999) No man alone: the rediscovery of Alois Alzheimer's original cases. Brain Pathol 9:237-240

4. Alzheimer A, Stelzmann RA, Schnitzlein HN, Murtagh FR (1995) An English translation of Alzheimer's 1907 paper, "Uber eine eigenartige Erkankung der Hirnrinde". Clin Anat 8: 429-431

5. Goedert M (2009) Oskar Fischer and the study of dementia. Brain 132:1102-1111

6. Selkoe DJ (2002) Alzheimer's disease is a synaptic failure. Science 298:789-791

7. Glenner GG, Wong CW (1984) Alzheimer's disease: initial report of the purification and characterization of a novel cerebrovascular amyloid protein. Biochem Biophys Res Commun 120:885-890

8. Masters CL, Simms G, Weinman NA, Multhaup G, McDonald BL, Beyreuther K (1985) Amyloid plaque core protein in Alzheimer disease and Down syndrome. Proc Natl Acad Sci USA 82:4245-4249

9. Vassar R, Bennett BD, Babu-Khan S, Kahn S, Mendiaz EA, Denis P, Teplow DB, Ross S, Amarante P, Loeloff R, Luo Y, Fisher S, Fuller J, Edenson S, Lile J, Jarosinski MA, Biere AL, Curran E, Burgess T, Louis JC, Collins F, Treanor J, Rogers G, Citron M (1999) Beta-secretase cleavage of Alzheimer's amyloid precursor protein by the transmembrane aspartic protease BACE. Science 286:735-741

10. Edbauer D, Winkler E, Regula JT, Pesold B, Steiner H, Haass C (2003) Reconstitution of gamma-secretase activity. Nat Cell Biol 5:486-488

11. Gotz J, Ittner LM (2008) Animal models of Alzheimer's disease and frontotemporal dementia. Nat Rev Neurosci 9:532-544

12. Lee VM, Goedert M, Trojanowski JQ (2001) Neurodegenerative tauopathies. Annu Rev Neurosci 24:1121-1159

13. Grundke-Iqbal I, Iqbal K, Tung YC, Quinlan M, Wisniewski HM, Binder LI (1986) Abnormal phosphorylation of the microtubule-associated protein tau (tau) in Alzheimer cytoskeletal pathology. Proc Natl Acad Sci USA 83:4913-4917

14. Goedert M, Wischik CM, Crowther RA, Walker JE, Klug A (1988) Cloning and sequencing of the cDNA encoding a core protein of the paired helical filament of Alzheimer disease: identification as the microtubule-associated protein tau. Proc Natl Acad Sci USA 85:4051-4055

15. Matus A (1990) Microtubule-associated proteins and the determination of neuronal form. J Physiol (Paris) 84:134-137

16. Ittner LM, Ke YD, Delerue F, Bi M, Gladbach A, van Eersel J, Wolfing H, Chieng BC, Christie MJ, Napier IA, Eckert A, Staufenbiel M, Hardeman E, Gotz J (2010) Dendritic function of tau mediates amyloid-beta toxicity in Alzheimer's disease mouse models. Cell 142:387-397

17. Chen F, David D, Ferrari A, Gotz J (2004) Posttranslational modifications of tau-role in human tauopathies and modeling in transgenic animals. Curr Drug Targets 5:503-515

18. Kopke E, Tung YC, Shaikh S, Alonso AC, Iqbal K, GrundkeIqbal I (1993) Microtubule-associated protein tau abnormal phosphorylation of a non-paired helical filament pool in Alzheimer disease. J Biol Chem 268:24374-24384

19. Jicha GA, Bowser R, Kazam IG, Davies P (1997) Alz-50 and $\mathrm{MC}-1$, a new monoclonal antibody raised to paired helical filaments, recognize conformational epitopes on recombinant tau. J Neurosci Res 48:128-132

20. Harper JD, Lansbury PT Jr (1997) Models of amyloid seeding in Alzheimer's disease and scrapie: mechanistic truths and physiological consequences of the time-dependent solubility of amyloid proteins. Annu Rev Biochem 66:385-407

21. Hortschansky P, Schroeckh V, Christopeit T, Zandomeneghi G, Fandrich M (2005) The aggregation kinetics of Alzheimer's beta-amyloid peptide is controlled by stochastic nucleation. Protein Sci 14:1753-1759

22. Pellarin R, Caflisch A (2006) Interpreting the aggregation kinetics of amyloid peptides. J Mol Biol 360:882-892

23. Gotz J, Ittner LM, Fandrich M, Schonrock N (2008) Is tau aggregation toxic or protective: a sensible question in the absence of sensitive methods? J Alzheimers Dis 14:423-429

24. Gotz J (2001) Tau and transgenic animal models. Brain Res Brain Res Rev 35:266-286

25. Kurosinski P, Gotz J (2002) Glial cells under physiologic and pathological conditions. Arch Neurol 59:1524-1528

26. Arnold SE, Hyman BT, Flory J, Damasio AR, Van Hoesen GW (1991) The topographical and neuroanatomical distribution of neurofibrillary tangles and neuritic plaques in the cerebral cortex of patients with Alzheimer's disease. Cereb Cortex 1:103-116

27. Braak H, Braak E (1991) Neuropathological stageing of Alzheimer-related changes. Acta Neuropathol (Berl) 82:239-259

28. Braak H, Braak E (1995) Staging of Alzheimer's disease-related neurofibrillary changes. Neurobiol Aging 16:271-278 (discussion 278-284)

29. Delacourte A, Sergeant N, Champain D, Wattez A, Maurage CA, Lebert F, Pasquier F, David JP (2002) Nonoverlapping but synergetic tau and APP pathologies in sporadic Alzheimer's disease. Neurology 59:398-407

30. Bertram L, Tanzi RE (2008) Thirty years of Alzheimer's disease genetics: the implications of systematic meta-analyses. Nat Rev Neurosci 9:768-778

31. Lambert JC, Heath S, Even G, Campion D, Sleegers K, Hiltunen $\mathrm{M}$, Combarros O, Zelenika D, Bullido MJ, Tavernier B, Letenneur L, Bettens K, Berr C, Pasquier F, Fievet N, BarbergerGateau P, Engelborghs S, De Deyn P, Mateo I, Franck A, Helisalmi S, Porcellini E, Hanon O, de Pancorbo MM, Lendon C, Dufouil C, Jaillard C, Leveillard T, Alvarez V, Bosco P, Mancuso M, Panza F, Nacmias B, Bossu P, Piccardi P, Annoni G, Seripa D, Galimberti D, Hannequin D, Licastro F, Soininen H, Ritchie K, Blanche H, Dartigues JF, Tzourio C, Gut I, Van Broeckhoven C, Alperovitch A, Lathrop M, Amouyel P (2009) Genome-wide association study identifies variants at CLU and CR1 associated with Alzheimer's disease. Nat Genet 41:1094-1099 
32. Harold D, Abraham R, Hollingworth P, Sims R, Gerrish A, Hamshere ML, Pahwa JS, Moskvina V, Dowzell K, Williams A, Jones N, Thomas C, Stretton A, Morgan AR, Lovestone S, Powell J, Proitsi P, Lupton MK, Brayne C, Rubinsztein DC, Gill M, Lawlor B, Lynch A, Morgan K, Brown KS, Passmore PA, Craig D, McGuinness B, Todd S, Holmes C, Mann D, Smith AD, Love S, Kehoe PG, Hardy J, Mead S, Fox N, Rossor M, Collinge J, Maier W, Jessen F, Schurmann B, van den Bussche H, Heuser I, Kornhuber J, Wiltfang J, Dichgans M, Frolich L, Hampel H, Hull M, Rujescu D, Goate AM, Kauwe JS, Cruchaga C, Nowotny P, Morris JC, Mayo K, Sleegers K, Bettens K, Engelborghs S, De Deyn PP, Van Broeckhoven C, Livingston G, Bass NJ, Gurling H, McQuillin A, Gwilliam R, Deloukas P, Al-Chalabi A, Shaw CE, Tsolaki M, Singleton AB, Guerreiro R, Muhleisen TW, Nothen MM, Moebus S, Jockel KH, Klopp N, Wichmann HE, Carrasquillo MM, Pankratz VS, Younkin SG, Holmans PA, O’Donovan M, Owen MJ, Williams J (2009) Genome-wide association study identifies variants at CLU and PICALM associated with Alzheimer's disease. Nat Genet 41:1088-1093

33. Jun G, Naj AC, Beecham GW, Wang LS, Buros J, Gallins PJ, Buxbaum JD, Ertekin-Taner N, Fallin MD, Friedland R, Inzelberg R, Kramer P, Rogaeva E, St George-Hyslop P, Cantwell LB, Dombroski BA, Saykin AJ, Reiman EM, Bennett DA, Morris JC, Lunetta KL, Martin ER, Montine TJ, Goate AM, Blacker D, Tsuang DW, Beekly D, Cupples LA, Hakonarson H, Kukull W, Foroud TM, Haines J, Mayeux R, Farrer LA, PericakVance MA, Schellenberg GD (2010) Meta-analysis confirms CR1, CLU, and PICALM as alzheimer disease risk loci and reveals interactions with APOE genotypes. Arch Neurol 67:1473-1484

34. Hodges JR, Davies RR, Xuereb JH, Casey B, Broe M, Bak TH, Kril JJ, Halliday GM (2004) Clinicopathological correlates in frontotemporal dementia. Ann Neurol 56:399-406

35. Hutton M, Lendon CL, Rizzu P, Baker M, Froelich S, Houlden $\mathrm{H}$, Pickering-Brown S, Chakraverty S, Isaacs A, Grover A, Hackett J, Adamson J, Lincoln S, Dickson D, Davies P, Petersen RC, Stevens M, de Graaff E, Wauters E, van Baren J, Hillebrand M, Joosse M, Kwon JM, Nowotny P, Heutink P et al (1998) Association of missense and $5^{\prime}$-splice-site mutations in tau with the inherited dementia FTDP-17. Nature 393:702-705

36. Poorkaj P, Bird TD, Wijsman E, Nemens E, Garruto RM, Anderson L, Andreadis A, Wiederholt WC, Raskind M, Schellenberg GD (1998) Tau is a candidate gene for chromosome 17 frontotemporal dementia. Ann Neurol 43:815-825

37. Spillantini MG, Murrell JR, Goedert M, Farlow MR, Klug A, Ghetti B (1998) Mutation in the tau gene in familial multiple system tauopathy with presenile dementia. Proc Natl Acad Sci USA 95:7737-7741

38. Baker M, Mackenzie IR, Pickering-Brown SM, Gass J, Rademakers R, Lindholm C, Snowden J, Adamson J, Sadovnick AD, Rollinson S, Cannon A, Dwosh E, Neary D, Melquist S, Richardson A, Dickson D, Berger Z, Eriksen J, Robinson T, Zehr C, Dickey CA, Crook R, McGowan E, Mann D, Boeve B, Feldman $\mathrm{H}$, Hutton M (2006) Mutations in progranulin cause tau-negative frontotemporal dementia linked to chromosome 17. Nature 442:916-919

39. Cruts M, Gijselinck I, van der Zee J, Engelborghs S, Wils H, Pirici D, Rademakers R, Vandenberghe R, Dermaut B, Martin JJ, van Duijn C, Peeters K, Sciot R, Santens P, De Pooter T, Mattheijssens M, Van den Broeck M, Cuijt I, Vennekens K, De Deyn PP, Kumar-Singh S, Van Broeckhoven C (2006) Null mutations in progranulin cause ubiquitin-positive frontotemporal dementia linked to chromosome 17q21. Nature 442:920-924

40. Neumann M, Sampathu DM, Kwong LK, Truax AC, Micsenyi MC, Chou TT, Bruce J, Schuck T, Grossman M, Clark CM,
McCluskey LF, Miller BL, Masliah E, Mackenzie IR, Feldman H, Feiden W, Kretzschmar HA, Trojanowski JQ, Lee VM (2006) Ubiquitinated TDP-43 in frontotemporal lobar degeneration and amyotrophic lateral sclerosis. Science 314:130-133

41. Mackenzie IR, Rademakers R, Neumann M (2010) TDP-43 and FUS in amyotrophic lateral sclerosis and frontotemporal dementia. Lancet Neurol 9:995-1007

42. Cruts M, Van Broeckhoven C (2008) Loss of progranulin function in frontotemporal lobar degeneration. Trends Genet 24(4):186-194

43. Mathias JL, Morphett K (2010) Neurobehavioral differences between Alzheimer's disease and frontotemporal dementia: a meta-analysis. J Clin Exp Neuropsychol 32:682-698

44. Villemagne VL, Pike KE, Chetelat G, Ellis KA, Mulligan RS, Bourgeat P, Ackermann U, Jones G, Szoeke C, Salvado O, Martins R, O'Keefe G, Mathis CA, Klunk WE, Ames D, Masters CL, Rowe CC (2011) Longitudinal assessment of abeta and cognition in aging and Alzheimer disease. Ann Neurol 69:181-192

45. Ittner LM, Gotz J (2011) Amyloid-beta and tau-a toxic pas de deux in Alzheimer's disease. Nat Rev Neurosci 12:65-72

46. Assal F, Cummings JL (2002) Neuropsychiatric symptoms in the dementias. Curr Opin Neurol 15:445-450

47. Neary D, Snowden JS, Gustafson L, Passant U, Stuss D, Black S, Freedman M, Kertesz A, Robert PH, Albert M, Boone K, Miller BL, Cummings J, Benson DF (1998) Frontotemporal lobar degeneration: a consensus on clinical diagnostic criteria [see comments]. Neurology 51:1546-1554

48. Walker AJ, Meares S, Sachdev PS, Brodaty H (2005) The differentiation of mild frontotemporal dementia from Alzheimer's disease and healthy aging by neuropsychological tests. Int Psychogeriatr 17:57-68

49. Snowden JS, Bathgate D, Varma A, Blackshaw A, Gibbons ZC, Neary D (2001) Distinct behavioural profiles in frontotemporal dementia and semantic dementia. J Neurol Neurosurg Psychiatry 70:323-332

50. Weder ND, Aziz R, Wilkins K, Tampi RR (2007) Frontotemporal dementias: a review. Ann Gen Psychiatry 6:15

51. Gotz J, Deters N, Doldissen A, Bokhari L, Ke Y, Wiesner A, Schonrock N, Ittner LM (2007) A decade of tau transgenic animal models and beyond. Brain Pathol 17:91-103

52. Games D, Adams D, Alessandrini R, Barbour R, Berthelette P, Blackwell C, Carr T, Clemens J, Donaldson T, Gillespie F et al (1995) Alzheimer-type neuropathology in transgenic mice overexpressing V717F beta-amyloid precursor protein. Nature 373:523-527 (see comments)

53. Hsiao K, Chapman P, Nilsen S, Eckman C, Harigaya Y, Younkin S, Yang F, Cole G (1996) Correlative memory deficits, Abeta elevation, and amyloid plaques in transgenic mice. Science 274:99-102 (see comments)

54. Sturchler-Pierrat C, Abramowski D, Duke M, Wiederhold KH, Mistl C, Rothacher S, Ledermann B, Burki K, Frey P, Paganetti PA, Waridel C, Calhoun ME, Jucker M, Probst A, Staufenbiel M, Sommer B (1997) Two amyloid precursor protein transgenic mouse models with Alzheimer disease-like pathology. Proc Natl Acad Sci USA 94:13287-13292

55. Stalder M, Phinney A, Probst A, Sommer B, Staufenbiel M, Jucker M (1999) Association of microglia with amyloid plaques in brains of APP23 transgenic mice. Am J Pathol 154:16731684

56. Janus C, Pearson J, McLaurin J, Mathews PM, Jiang Y, Schmidt SD, Chishti MA, Horne P, Heslin D, French J, Mount HT, Nixon RA, Mercken M, Bergeron C, Fraser PE, St George-Hyslop P, Westaway D (2000) A beta peptide immunization reduces behavioural impairment and plaques in a model of Alzheimer's disease. Nature 408:979-982 
57. Mucke L, Masliah E, Yu GQ, Mallory M, Rockenstein EM, Tatsuno G, Hu K, Kholodenko D, Johnson-Wood K, McConlogue L (2000) High-level neuronal expression of abeta 1-42 in wildtype human amyloid protein precursor transgenic mice: synaptotoxicity without plaque formation. J Neurosci 20:4050-4058

58. Gotz J, Probst A, Spillantini MG, Schafer T, Jakes R, Burki K, Goedert M (1995) Somatodendritic localization and hyperphosphorylation of tau protein in transgenic mice expressing the longest human brain tau isoform. EMBO J 14:1304-1313

59. Ishihara $\mathrm{T}$, Hong $\mathrm{M}$, Zhang B, Nakagawa $\mathrm{Y}$, Lee MK, Trojanowski JQ, Lee VM (1999) Age-dependent emergence and progression of a tauopathy in transgenic mice overexpressing the shortest human tau isoform. Neuron 24:751-762

60. Spittaels K, Van den Haute C, Van Dorpe J, Bruynseels K, Vandezande K, Laenen I, Geerts H, Mercken M, Sciot R, Van Lommel A, Loos R, Van Leuven F (1999) Prominent axonopathy in the brain and spinal cord of transgenic mice overexpressing four-repeat human tau protein. Am J Pathol 155:2153-2165

61. Probst A, Gotz J, Wiederhold KH, Tolnay M, Mistl C, Jaton AL, Hong M, Ishihara T, Lee VM, Trojanowski JQ, Jakes R, Crowther RA, Spillantini MG, Burki K, Goedert M (2000) Axonopathy and amyotrophy in mice transgenic for human fourrepeat tau protein. Acta Neuropathol (Berl) 99:469-481

62. Gotz J, Nitsch RM (2001) Compartmentalized tau hyperphosphorylation and increased levels of kinases in transgenic mice. Neuroreport 12:2007-2016

63. Gotz J, Tolnay M, Barmettler R, Chen F, Probst A, Nitsch RM (2001) Oligodendroglial tau filament formation in transgenic mice expressing G272V tau. Eur J Neurosci 13:2131-2140

64. Gotz J, Chen F, Barmettler R, Nitsch RM (2001) Tau filament formation in transgenic mice expressing P301L tau. J Biol Chem 276:529-534

65. Gotz J, Chen F, van Dorpe J, Nitsch RM (2001) Formation of neurofibrillary tangles in P301L tau transgenic mice induced by Abeta 42 fibrils. Science 293:1491-1495

66. Kulic L, Kurosinski P, Chen F, Tracy J, Mohajeri MH, Li H, Nitsch RM, Gotz J (2005) Active immunization trial in Abeta(42)-injected P301L tau transgenic mice. Neurobiol Dis 22:50-56

67. Deters N, Ittner LM, Gotz J (2008) Divergent phosphorylation pattern of tau in P301L tau transgenic mice. Eur J Neurosci 28:137-147

68. Hundelt M, Fath T, Selle K, Oesterwind K, Jordan J, Schultz C, Gotz J, von Engelhardt J, Monyer H, Lewejohann L, Sachser N, Bakota L, Brandt R (2009) Altered phosphorylation but no neurodegeneration in a mouse model of tau hyperphosphorylation. Neurobiol Aging 32:991-1006

69. Pennanen L, Welzl H, D'Adamo P, Nitsch RM, Gotz J (2004) Accelerated extinction of conditioned taste aversion in P301L tau transgenic mice. Neurobiol Dis 15:500-509

70. Pennanen L, Wolfer DP, Nitsch RM, Gotz J (2006) Impaired spatial reference memory and increased exploratory behavior in P301L tau transgenic mice. Genes Brain Behav 5:369-379

71. Deters N, Ittner LM, Gotz J (2009) Substrate-specific reduction of PP2A activity exaggerates tau pathology. Biochem Biophys Res Commun 379:400-405

72. Ittner LM, Fath T, Ke YD, Bi M, van Eersel J, Li KM, Gunning P, Gotz J (2008) Parkinsonism and impaired axonal transport in a mouse model of frontotemporal dementia. Proc Natl Acad Sci USA 105:15997-16002

73. Ittner LM, Ke YD, Gotz J (2009) Phosphorylated Tau Interacts with c-Jun N-terminal Kinase-interacting Protein 1 (JIP1) in Alzheimer disease. J Biol Chem 284:20909-20916

74. Oddo S, Caccamo A, Shepherd JD, Murphy MP, Golde TE, Kayed R, Metherate R, Mattson MP, Akbari Y, LaFerla FM
(2003) Triple-transgenic model of Alzheimer's disease with plaques and tangles. Intracellular abeta and synaptic dysfunction. Neuron 39:409-421

75. Oddo S, Billings L, Kesslak JP, Cribbs DH, LaFerla FM (2004) Abeta immunotherapy leads to clearance of early, but not late, hyperphosphorylated tau aggregates via the proteasome. Neuron 43:321-332

76. Blurton-Jones M, Kitazawa M, Martinez-Coria H, Castello NA, Muller FJ, Loring JF, Yamasaki TR, Poon WW, Green KN, LaFerla FM (2009) Neural stem cells improve cognition via BDNF in a transgenic model of Alzheimer disease. Proc Natl Acad Sci USA 106:13594-13599

77. Grueninger F, Bohrmann B, Czech C, Ballard TM, Frey JR, Weidensteiner C, von Kienlin M, Ozmen L (2010) Phosphorylation of Tau at S422 is enhanced by Abeta in TauPS2APP triple transgenic mice. Neurobiol Dis 37:294-306

78. Rhein V, Song X, Wiesner A, Ittner LM, Baysang G, Meier F, Ozmen L, Bluethmann H, Drose S, Brandt U, Savaskan E, Czech C, Gotz J, Eckert A (2009) Amyloid-beta and tau synergistically impair the oxidative phosphorylation system in triple transgenic Alzheimer's disease mice. Proc Natl Acad Sci USA 106:20057-20062

79. Hardy J, Selkoe DJ (2002) The amyloid hypothesis of Alzheimer's disease: progress and problems on the road to therapeutics. Science 297:353-356

80. Gotz J, Schild A, Hoerndli F, Pennanen L (2004) Amyloidinduced neurofibrillary tangle formation in Alzheimer's disease: insight from transgenic mouse and tissue-culture models. Int $\mathrm{J}$ Dev Neurosci 22:453-465

81. Lewis J, Dickson DW, Lin W-L, Chisholm L, Corral A, Jones G, Yen S-H, Sahara N, Skipper L, Yager D, Eckman C, Hardy J, Hutton M, McGowan E (2001) Enhanced neurofibrillary degeneration in transgenic mice expressing mutant Tau and APP. Science 293:1487-1491

82. Ferrari A, Hoerndli F, Baechi T, Nitsch RM, Gotz J (2003) Betaamyloid induces PHF-like tau filaments in tissue culture. J Biol Chem 278:40162-40168

83. Pennanen L, Gotz J (2005) Different tau epitopes define Abeta(42)-mediated tau insolubility. Biochem Biophys Res Commun 337:1097-1101

84. Bolmont T, Clavaguera F, Meyer-Luehmann M, Herzig MC, Radde R, Staufenbiel M, Lewis J, Hutton M, Tolnay M, Jucker M (2007) Induction of tau pathology by intracerebral infusion of amyloid-beta -containing brain extract and by amyloid-beta deposition in APP $\times$ Tau transgenic mice. Am J Pathol 171: 2012-2020

85. Rapoport M, Dawson HN, Binder LI, Vitek MP, Ferreira A (2002) Tau is essential to beta -amyloid-induced neurotoxicity. Proc Natl Acad Sci USA 99:6364-6369

86. Roberson ED, Scearce-Levie K, Palop JJ, Yan F, Cheng IH, Wu T, Gerstein H, Yu GQ, Mucke L (2007) Reducing endogenous tau ameliorates amyloid beta-induced deficits in an Alzheimer's disease mouse model. Science 316:750-754

87. Shankar GM, Li S, Mehta TH, Garcia-Munoz A, Shepardson NE, Smith I, Brett FM, Farrell MA, Rowan MJ, Lemere CA, Regan CM, Walsh DM, Sabatini BL, Selkoe DJ (2008) Amyloid-beta protein dimers isolated directly from Alzheimer's brains impair synaptic plasticity and memory. Nat Med 14:837842

88. Palop JJ, Mucke L (2009) Epilepsy and cognitive impairments in Alzheimer disease. Arch Neurol 66:435-440

89. Small DH, Maksel D, Kerr ML, Ng J, Hou X, Chu C, Mehrani H, Unabia S, Azari MF, Loiacono R, Aguilar MI, Chebib M (2007) The beta-amyloid protein of Alzheimer's disease binds to membrane lipids but does not bind to the alpha7 nicotinic acetylcholine receptor. J Neurochem 101:1527-1538 
90. Kessels HW, Nguyen LN, Nabavi S, Malinow R (2010) The prion protein as a receptor for amyloid-beta. Nature 466:E3-E4 (discussion E4-E5)

91. Gu Z, Nakamura T, Lipton SA (2010) Redox reactions induced by nitrosative stress mediate protein misfolding and mitochondrial dysfunction in neurodegenerative diseases. Mol Neurobiol 41:55-72

92. Nikolaev A, McLaughlin T, O'Leary DD, Tessier-Lavigne M (2009) APP binds DR6 to trigger axon pruning and neuron death via distinct caspases. Nature 457:981-989

93. D’Amelio M, Cavallucci V, Middei S, Marchetti C, Pacioni S, Ferri A, Diamantini A, De Zio D, Carrara P, Battistini L, Moreno S, Bacci A, Ammassari-Teule M, Marie H, Cecconi F (2011) Caspase-3 triggers early synaptic dysfunction in a mouse model of Alzheimer's disease. Nat Neurosci 14:69-76

94. Budd SL, Tenneti L, Lishnak T, Lipton SA (2000) Mitochondrial and extramitochondrial apoptotic signaling pathways in cerebrocortical neurons. Proc Natl Acad Sci USA 97:6161-6166

95. Haass C, Mandelkow E (2010) Fyn-tau-amyloid: a toxic triad. Cell 142:356-358

96. Salter MW, Kalia LV (2004) Src kinases: a hub for NMDA receptor regulation. Nat Rev Neurosci 5:317-328

97. Aarts M, Liu Y, Liu L, Besshoh S, Arundine M, Gurd JW, Wang YT, Salter MW, Tymianski M (2002) Treatment of ischemic brain damage by perturbing NMDA receptor-PSD-95 protein interactions. Science 298:846-850

98. Vossel KA, Zhang K, Brodbeck J, Daub AC, Sharma P, Finkbeiner S, Cui B, Mucke L (2010) Tau reduction prevents Abeta-induced defects in axonal transport. Science 330:198

99. Harris JA, Devidze N, Verret L, Ho K, Halabisky B, Thwin MT, Kim D, Hamto P, Lo I, Yu GQ, Palop JJ, Masliah E, Mucke L (2010) Transsynaptic progression of amyloid-beta-induced neuronal dysfunction within the entorhinal-hippocampal network. Neuron 68:428-441

100. Cappai R, Barnham KJ (2008) Delineating the mechanism of Alzheimer's disease Abeta peptide neurotoxicity. Neurochem Res 33:526-532

101. Lim YA, Ittner LM, Lim YL, Gotz J (2008) Human but not rat amylin shares neurotoxic properties with Abeta42 in long-term hippocampal and cortical cultures. FEBS Lett 582:2188-2194

102. Gotz J, Ittner LM, Lim YA (2009) Common features between diabetes mellitus and Alzheimer's disease. Cell Mol Life Sci 66:1321-1325

103. Bhatia R, Lin H, Lal R (2000) Fresh and globular amyloid beta protein (1-42) induces rapid cellular degeneration: evidence for AbetaP channel-mediated cellular toxicity. FASEB J 14:12331243

104. Ambroggio EE, Kim DH, Separovic F, Barrow CJ, Barnham KJ, Bagatolli LA, Fidelio GD (2005) Surface behavior and lipid interaction of Alzheimer beta-amyloid peptide 1-42: a membrane-disrupting peptide. Biophys J 88:2706-2713

105. Lau TL, Ambroggio EE, Tew DJ, Cappai R, Masters CL, Fidelio GD, Barnham KJ, Separovic F (2006) Amyloid-beta peptide disruption of lipid membranes and the effect of metal ions. $\mathbf{J}$ Mol Biol 356:759-770

106. Arispe N, Rojas E, Pollard HB (1993) Alzheimer disease amyloid beta protein forms calcium channels in bilayer membranes: blockade by tromethamine and aluminum. Proc Natl Acad Sci USA 90:567-571

107. Pollard HB, Arispe N, Rojas E (1995) Ion channel hypothesis for Alzheimer amyloid peptide neurotoxicity. Cell Mol Neurobiol 15:513-526

108. Holscher C (1998) Possible causes of Alzheimer's disease: amyloid fragments, free radicals, and calcium homeostasis. Neurobiol Dis 5:129-141
109. Lin H, Bhatia R, Lal R (2001) Amyloid beta protein forms ion channels: implications for Alzheimer's disease pathophysiology. FASEB J 15:2433-2444

110. Demuro A, Mina E, Kayed R, Milton SC, Parker I, Glabe CG (2005) Calcium dysregulation and membrane disruption as a ubiquitous neurotoxic mechanism of soluble amyloid oligomers. J Biol Chem 280:17294-17300

111. Hardingham GE, Bading H (2010) Synaptic versus extrasynaptic NMDA receptor signalling: implications for neurodegenerative disorders. Nat Rev Neurosci 11:682-696

112. Small DH, Mok SS, Bornstein JC (2001) Alzheimer's disease and Abeta toxicity: from top to bottom. Nat Rev Neurosci 2:595-598

113. Wang Q, Walsh DM, Rowan MJ, Selkoe DJ, Anwyl R (2004) Block of long-term potentiation by naturally secreted and synthetic amyloid beta-peptide in hippocampal slices is mediated via activation of the kinases c-Jun N-terminal kinase, cyclindependent kinase 5, and p38 mitogen-activated protein kinase as well as metabotropic glutamate receptor type 5. J Neurosci 24:3370-3378

114. Minogue AM, Schmid AW, Fogarty MP, Moore AC, Campbell VA, Herron CE, Lynch MA (2003) Activation of the c-Jun $\mathrm{N}$-terminal kinase signaling cascade mediates the effect of amyloid-beta on long term potentiation and cell death in hippocampus: a role for interleukin-1beta? J Biol Chem 278:27971-27980

115. Kins S, Crameri A, Evans DR, Hemmings BA, Nitsch RM, Gotz J (2001) Reduced PP2A activity induces hyperphosphorylation and altered compartmentalization of tau in transgenic mice. $\mathrm{J}$ Biol Chem 276:38193-38200

116. Kins S, Kurosinski P, Nitsch RM, Gotz J (2003) Activation of the ERK and JNK signaling pathways caused by neuron specific inhibition of PP2A in transgenic mice. Am J Pathol 163:833843

117. Chong YH, Shin YJ, Lee EO, Kayed R, Glabe CG, Tenner AJ (2006) ERK1/2 activation mediates Abeta oligomer-induced neurotoxicity via caspase- 3 activation and tau cleavage in rat organotypic hippocampal slice cultures. J Biol Chem 281:20315-20325

118. Lee G, Newman ST, Gard DL, Band H, Panchamoorthy G (1998) Tau interacts with src-family non-receptor tyrosine kinases. J Cell Sci 111:3167-3177

119. Lee G, Thangavel R, Sharma VM, Litersky JM, Bhaskar K, Fang SM, Do LH, Andreadis A, Van Hoesen G, Ksiezak-Reding $\mathrm{H}$ (2004) Phosphorylation of tau by fyn: implications for Alzheimer's disease. J Neurosci 24:2304-2312

120. Lambert MP, Barlow AK, Chromy BA, Edwards C, Freed R, Liosatos M, Morgan TE, Rozovsky I, Trommer B, Viola KL, Wals P, Zhang C, Finch CE, Krafft GA, Klein WL (1998) Diffusible, nonfibrillar ligands derived from Abeta1-42 are potent central nervous system neurotoxins. Proc Natl Acad Sci USA 95:6448-6453

121. Chin J, Palop JJ, Yu GQ, Kojima N, Masliah E, Mucke L (2004) Fyn kinase modulates synaptotoxicity, but not aberrant sprouting, in human amyloid precursor protein transgenic mice. J Neurosci 24:4692-4697

122. Chin J, Palop JJ, Puolivali J, Massaro C, Bien-Ly N, Gerstein H, Scearce-Levie K, Masliah E, Mucke L (2005) Fyn kinase induces synaptic and cognitive impairments in a transgenic mouse model of Alzheimer's disease. J Neurosci 25:9694-9703

123. Braithwaite SP, Paul S, Nairn AC, Lombroso PJ (2006) Synaptic plasticity: one STEP at a time. Trends Neurosci 29:452-458

124. Roberson ED, Halabisky B, Yoo JW, Yao J, Chin J, Yan F, Wu T, Hamto P, Devidze N, Yu GQ, Palop JJ, Noebels JL, Mucke L (2011) Amyloid-beta/Fyn-induced synaptic, network, and 
cognitive impairments depend on tau levels in multiple mouse models of Alzheimer's disease. J Neurosci 31:700-711

125. Snyder EM, Nong Y, Almeida CG, Paul S, Moran T, Choi EY, Nairn AC, Salter MW, Lombroso PJ, Gouras GK, Greengard P (2005) Regulation of NMDA receptor trafficking by amyloidbeta. Nat Neurosci 8:1051-1058

126. Abramov AY, Canevari L, Duchen MR (2004) Calcium signals induced by amyloid beta peptide and their consequences in neurons and astrocytes in culture. Biochim Biophys Acta 1742:81-87

127. Hartley DM, Walsh DM, Ye CP, Diehl T, Vasquez S, Vassilev PM, Teplow DB, Selkoe DJ (1999) Protofibrillar intermediates of amyloid beta-protein induce acute electrophysiological changes and progressive neurotoxicity in cortical neurons. J Neurosci 19:8876-8884

128. Necula M, Kayed R, Milton S, Glabe CG (2007) Small molecule inhibitors of aggregation indicate that amyloid beta oligomerization and fibrillization pathways are independent and distinct. J Biol Chem 282:10311-10324

129. Yankner BA, Duffy LK, Kirschner DA (1990) Neurotrophic and neurotoxic effects of amyloid beta protein: reversal by tachykinin neuropeptides. Science 250:279-282

130. Pike CJ, Walencewicz AJ, Glabe CG, Cotman CW (1991) In vitro aging of beta-amyloid protein causes peptide aggregation and neurotoxicity. Brain Res 563:311-314

131. Pike CJ, Walencewicz AJ, Glabe CG, Cotman CW (1991) Aggregation-related toxicity of synthetic beta-amyloid protein in hippocampal cultures. Eur J Pharmacol 207:367-368

132. Pike CJ, Burdick D, Walencewicz AJ, Glabe CG, Cotman CW (1993) Neurodegeneration induced by beta-amyloid peptides in vitro: the role of peptide assembly state. J Neurosci 13:16761687

133. Walsh DM, Klyubin I, Fadeeva JV, Cullen WK, Anwyl R, Wolfe MS, Rowan MJ, Selkoe DJ (2002) Naturally secreted oligomers of amyloid beta protein potently inhibit hippocampal long-term potentiation in vivo. Nature 416:535-539

134. Smith DP, Ciccotosto GD, Tew DJ, Fodero-Tavoletti MT, Johanssen T, Masters CL, Barnham KJ, Cappai R (2007) Concentration dependent $\mathrm{Cu}^{2+}$ induced aggregation and dityrosine formation of the Alzheimer's disease amyloid-beta peptide. Biochemistry 46:2881-2891

135. Glabe CG (2008) Structural classification of toxic amyloid oligomers. J Biol Chem 283:29639-29643

136. Barghorn S, Nimmrich V, Striebinger A, Krantz C, Keller P, Janson B, Bahr M, Schmidt M, Bitner RS, Harlan J, Barlow E, Ebert U, Hillen H (2005) Globular amyloid beta-peptide oligomer-a homogenous and stable neuropathological protein in Alzheimer's disease. J Neurochem 95:834-847

137. Lesne S, Koh MT, Kotilinek L, Kayed R, Glabe CG, Yang A, Gallagher M, Ashe KH (2006) A specific amyloid-beta protein assembly in the brain impairs memory. Nature 440:352-357

138. Ahmed M, Davis J, Aucoin D, Sato T, Ahuja S, Aimoto S, Elliott JI, Van Nostrand WE, Smith SO (2010) Structural conversion of neurotoxic amyloid-beta(1-42) oligomers to fibrils. Nat Struct Mol Biol 17:561-567

139. Habicht G, Haupt C, Friedrich RP, Hortschansky P, Sachse C, Meinhardt J, Wieligmann K, Gellermann GP, Brodhun M, Gotz J, Halbhuber KJ, Rocken C, Horn U, Fandrich M (2007) Directed selection of a conformational antibody domain that prevents mature amyloid fibril formation by stabilizing Abeta protofibrils. Proc Natl Acad Sci USA 104:19232-19237

140. Klyubin I, Walsh DM, Lemere CA, Cullen WK, Shankar GM, Betts V, Spooner ET, Jiang L, Anwyl R, Selkoe DJ, Rowan MJ (2005) Amyloid beta protein immunotherapy neutralizes Abeta oligomers that disrupt synaptic plasticity in vivo. Nat Med 11:556-561
141. Trommer BL, Shah C, Yun SH, Gamkrelidze G, Pasternak ES, Stine WB, Manelli A, Sullivan P, Pasternak JF, LaDu MJ (2005) ApoE isoform-specific effects on LTP: blockade by oligomeric amyloid-beta1-42. Neurobiol Dis 18:75-82

142. Cleary JP, Walsh DM, Hofmeister JJ, Shankar GM, Kuskowski MA, Selkoe DJ, Ashe KH (2005) Natural oligomers of the amyloid-beta protein specifically disrupt cognitive function. Nat Neurosci 8:79-84

143. Walsh DM, Klyubin I, Shankar GM, Townsend M, Fadeeva JV, Betts V, Podlisny MB, Cleary JP, Ashe KH, Rowan MJ, Selkoe DJ (2005) The role of cell-derived oligomers of Abeta in Alzheimer's disease and avenues for therapeutic intervention. Biochem Soc Trans 33:1087-1090

144. Stine WB Jr, Dahlgren KN, Krafft GA, LaDu MJ (2003) In vitro characterization of conditions for amyloid-beta peptide oligomerization and fibrillogenesis. J Biol Chem 278:11612-11622

145. White JA, Manelli AM, Holmberg KH, Van Eldik LJ, Ladu MJ (2005) Differential effects of oligomeric and fibrillar amyloidbeta $1-42$ on astrocyte-mediated inflammation. Neurobiol Dis 18:459-465

146. Jin M, Shepardson N, Yang T, Chen G, Walsh D, Selkoe DJ (2011) Soluble amyloid \{beta\}-protein dimers isolated from Alzheimer cortex directly induce Tau hyperphosphorylation and neuritic degeneration. Proc Natl Acad Sci USA 108:5819-5824

147. Iijima K, Liu HP, Chiang AS, Hearn SA, Konsolaki M, Zhong Y (2004) Dissecting the pathological effects of human Abeta40 and Abeta42 in Drosophila: a potential model for Alzheimer's disease. Proc Natl Acad Sci USA 101:6623-6628

148. Luheshi LM, Tartaglia GG, Brorsson AC, Pawar AP, Watson IE, Chiti F, Vendruscolo M, Lomas DA, Dobson CM, Crowther DC (2007) Systematic in vivo analysis of the intrinsic determinants of amyloid Beta pathogenicity. PLoS Biol 5:e290

149. Yan Y, Wang C (2007) Abeta40 protects non-toxic Abeta42 monomer from aggregation. J Mol Biol 369:909-916

150. Verdier Y, Zarandi M, Penke B (2004) Amyloid beta-peptide interactions with neuronal and glial cell plasma membrane: binding sites and implications for Alzheimer's disease. J Pept Sci 10:229-248

151. Shibata M, Yamada S, Kumar SR, Calero M, Bading J, Frangione B, Holtzman DM, Miller CA, Strickland DK, Ghiso J, Zlokovic BV (2000) Clearance of Alzheimer's amyloid-beta (1-40) peptide from brain by LDL receptor-related protein-1 at the blood-brain barrier. J Clin Invest 106:1489-1499

152. Deane R, Wu Z, Sagare A, Davis J, Du Yan S, Hamm K, Xu F, Parisi M, LaRue B, Hu HW, Spijkers P, Guo H, Song X, Lenting PJ, Van Nostrand WE, Zlokovic BV (2004) LRP/amyloid betapeptide interaction mediates differential brain efflux of Abeta isoforms. Neuron 43:333-344

153. Mawuenyega KG, Sigurdson W, Ovod V, Munsell L, Kasten T, Morris JC, Yarasheski KE, Bateman RJ (2010) Decreased clearance of CNS beta-amyloid in Alzheimer's disease. Science 330:1774

154. Ellis RJ, Olichney JM, Thal LJ, Mirra SS, Morris JC, Beekly D, Heyman A (1996) Cerebral amyloid angiopathy in the brains of patients with Alzheimer's disease: the CERAD experience, Part XV. Neurology 46:1592-1596

155. Coulson EJ (2006) Does the p75 neurotrophin receptor mediate Abeta-induced toxicity in Alzheimer's disease? J Neurochem 98:654-660

156. Sotthibundhu A, Sykes AM, Fox B, Underwood CK, Thangnipon W, Coulson EJ (2008) Beta-amyloid(1-42) induces neuronal death through the p75 neurotrophin receptor. J Neurosci 28:3941-3946

157. Zhang Y, Hong Y, Bounhar Y, Blacker M, Roucou X, Tounekti O, Vereker E, Bowers WJ, Federoff HJ, Goodyer CG, LeBlanc A (2003) p75 Neurotrophin receptor protects primary cultures of 
human neurons against extracellular amyloid beta peptide cytotoxicity. J Neurosci 23:7385-7394

158. Perini G, Della-Bianca V, Politi V, Della Valle G, Dal-Pra I, Rossi F, Armato U (2002) Role of p75 neurotrophin receptor in the neurotoxicity by beta-amyloid peptides and synergistic effect of inflammatory cytokines. J Exp Med 195:907-918

159. De Felice FG, Velasco PT, Lambert MP, Viola K, Fernandez SJ, Ferreira ST, Klein WL (2007) Abeta oligomers induce neuronal oxidative stress through an $N$-methyl-D-aspartate receptordependent mechanism that is blocked by the Alzheimer drug memantine. J Biol Chem 282:11590-11601

160. Lustbader JW, Cirilli M, Lin C, Xu HW, Takuma K, Wang N, Caspersen C, Chen X, Pollak S, Chaney M, Trinchese F, Liu S, Gunn-Moore F, Lue LF, Walker DG, Kuppusamy P, Zewier ZL, Arancio O, Stern D, Yan SS, Wu H (2004) ABAD directly links Abeta to mitochondrial toxicity in Alzheimer's disease. Science 304:448-452

161. Crouch PJ, Blake R, Duce JA, Ciccotosto GD, Li QX, Barnham KJ, Curtain CC, Cherny RA, Cappai R, Dyrks T, Masters CL, Trounce IA (2005) Copper-dependent inhibition of human cytochrome c oxidase by a dimeric conformer of amyloidbeta1-42. J Neurosci 25:672-679

162. Caspersen C, Wang N, Yao J, Sosunov A, Chen X, Lustbader JW, Xu HW, Stern D, McKhann G, Yan SD (2005) Mitochondrial Abeta: a potential focal point for neuronal metabolic dysfunction in Alzheimer's disease. FASEB J 19:2040-2041

163. Devi L, Prabhu BM, Galati DF, Avadhani NG, Anandatheerthavarada HK (2006) Accumulation of amyloid precursor protein in the mitochondrial import channels of human Alzheimer's disease brain is associated with mitochondrial dysfunction. $\mathrm{J}$ Neurosci 26:9057-9068

164. Manczak M, Anekonda TS, Henson E, Park BS, Quinn J, Reddy PH (2006) Mitochondria are a direct site of Abeta accumulation in Alzheimer's disease neurons: implications for free radical generation and oxidative damage in disease progression. Hum Mol Genet 15:1437-1449

165. Keil U, Bonert A, Marques CA, Scherping I, Weyermann J, Strosznajder JB, Muller-Spahn F, Haass C, Czech C, Pradier L, Muller WE, Eckert A (2004) Amyloid beta-induced changes in nitric oxide production and mitochondrial activity lead to apoptosis. J Biol Chem 279:50310-50320

166. David DC, Hauptmann S, Scherping I, Schuessel K, Keil U, Rizzu P, Ravid R, Dröse S, Brandt U, Müller WE, Eckert E, Gotz J (2005) Proteomic and functional analysis reveal a mitochondrial dysfunction in P301L tau transgenic mice. J Biol Chem 280:23802-23814

167. Eckert A, Hauptmann S, Scherping I, Meinhardt J, Rhein V, Drose S, Brandt U, Fandrich M, Muller WE, Gotz J (2008) Oligomeric and fibrillar species of $\beta$-amyloid (A $\beta 42)$ both impair mitochondrial function in $\mathrm{P} 301 \mathrm{~L}$ tau transgenic mice. $\mathrm{J}$ Mol Med 86:1255-1267

168. Eckert A, Hauptmann S, Scherping I, Rhein V, Muller-Spahn F, Gotz J, Muller WE (2008) Soluble beta-amyloid leads to mitochondrial defects in amyloid precursor protein and tau transgenic mice. Neurodegener Dis 5:157-159

169. Eckert A, Schulz KL, Rhein V, Gotz J (2010) Convergence of amyloid-beta and tau pathologies on mitochondria in vivo. Mol Neurobiol 41:107-114

170. Hoerndli FJ, Pelech S, Papassotiropoulos A, Götz J (2007) Abeta treatment and P301L tau expression in an Alzheimer's disease tissue culture model act synergistically to promote aberrant cell cycle re-entry. Eur J Neurosci 26:60-72

171. Anandatheerthavarada HK, Biswas G, Robin MA, Avadhani NG (2003) Mitochondrial targeting and a novel transmembrane arrest of Alzheimer's amyloid precursor protein impairs mitochondrial function in neuronal cells. J Cell Biol 161:41-54
172. Takuma K, Yao J, Huang J, Xu H, Chen X, Luddy J, Trillat AC, Stern DM, Arancio O, Yan SS (2005) ABAD enhances Abetainduced cell stress via mitochondrial dysfunction. FASEB J 19:597-598

173. Yan Y, Liu Y, Sorci M, Belfort G, Lustbader JW, Yan SS, Wang C (2007) Surface plasmon resonance and nuclear magnetic resonance studies of $\mathrm{ABAD}-\mathrm{Abeta}$ interaction. Biochemistry 46:1724-1731

174. Ivins KJ, Bui ET, Cotman CW (1998) Beta-amyloid induces local neurite degeneration in cultured hippocampal neurons: evidence for neuritic apoptosis. Neurobiol Dis 5:365-378

175. White AR, Guirguis R, Brazier MW, Jobling MF, Hill AF, Beyreuther K, Barrow CJ, Masters CL, Collins SJ, Cappai R (2001) Sublethal concentrations of prion peptide PrP106-126 or the amyloid beta peptide of Alzheimer's disease activates expression of proapoptotic markers in primary cortical neurons. Neurobiol Dis 8:299-316

176. Casas C, Sergeant N, Itier JM, Blanchard V, Wirths O, van der Kolk N, Vingtdeux V, van de Steeg E, Ret G, Canton T, Drobecq H, Clark A, Bonici B, Delacourte A, Benavides J, Schmitz C, Tremp G, Bayer TA, Benoit P, Pradier L (2004) Massive $\mathrm{CA} 1 / 2$ neuronal loss with intraneuronal and $\mathrm{N}$-terminal truncated Abeta42 accumulation in a novel Alzheimer transgenic model. Am J Pathol 165:1289-1300

177. Gomez-Ramos P, Asuncion Moran M (2007) Ultrastructural localization of intraneuronal Abeta-peptide in Alzheimer disease brains. J Alzheimers Dis 11:53-59

178. Wegiel J, Kuchna I, Nowicki K, Frackowiak J, Mazur-Kolecka B, Imaki H, Wegiel J, Mehta PD, Silverman WP, Reisberg B, Deleon M, Wisniewski T, Pirttilla T, Frey H, Lehtimaki T, Kivimaki T, Visser FE, Kamphorst W, Potempska A, Bolton D, Currie JR, Miller DL (2007) Intraneuronal Abeta immunoreactivity is not a predictor of brain amyloidosis-beta or neurofibrillary degeneration. Acta Neuropathol 113:389-402

179. Eckert A, Schmitt K, Gotz J (2011) Mitochondrial dysfunction-the beginning of the end in Alzheimer's disease? Separate and synergistic modes of tau and amyloid-beta toxicity. Alzheimers Res Ther 3:15

180. Hoerndli F, David D, Gotz J (2005) Functional genomics meets neurodegenerative disorders. Part II: application and data integration. Prog Neurobiol 76:169-188

181. Sowell RA, Owen JB, Butterfield DA (2009) Proteomics in animal models of Alzheimer's and Parkinson's diseases. Ageing Res Rev 8:1-17

182. Chen F, Wollmer MA, Hoerndli F, Münch G, Kuhla B, Rogaev EI, Tsolaki M, Papassotiropoulos A, Gotz J (2004) Role for glyoxalase I in Alzheimer's disease. Proc Natl Acad Sci USA 101:7687-7692

183. Hoerndli FJ, Toigo M, Schild A, Gotz J, Day PJ (2004) Reference genes identified in SH-SY5Y cells using custom-made gene arrays with validation by quantitative polymerase chain reaction. Anal Biochem 335:30-41

184. David DC, Ittner LM, Gehrig P, Nergenau D, Shepherd C, Halliday G, Gotz J (2006) $\beta$-Amyloid treatment of two complementary P301L tau-expressing Alzheimer's disease models reveals similar deregulated cellular processes. Proteomics 6:6566-6577

185. Schonrock N, Ke YD, Humphreys D, Staufenbiel M, Ittner LM, Preiss T, Gotz J (2010) Neuronal microRNA deregulation in response to Alzheimer's disease amyloid-beta. PLoS ONE 5:e11070

186. Hebert SS, De Strooper B (2009) Alterations of the microRNA network cause neurodegenerative disease. Trends Neurosci 32:199-206

187. Wang WX, Wilfred BR, Madathil SK, Tang G, Hu Y, Dimayuga J, Stromberg AJ, Huang Q, Saatman KE, Nelson PT (2010) 
miR-107 Regulates granulin/progranulin with implications for traumatic brain injury and neurodegenerative disease. Am J Pathol 177:334-345

188. Vilardo E, Barbato C, Ciotti M, Cogoni C, Ruberti F (2010) MicroRNA-101 regulates amyloid precursor protein expression in hippocampal neurons. J Biol Chem 285:18344-18351

189. Siomi H, Siomi MC (2010) Posttranscriptional regulation of microRNA biogenesis in animals. Mol Cell 38:323-332

190. Fabian MR, Sonenberg N, Filipowicz W (2010) Regulation of mRNA translation and stability by microRNAs. Annu Rev Biochem 79:351-379

191. Wang WX, Rajeev BW, Stromberg AJ, Ren N, Tang G, Huang Q, Rigoutsos I, Nelson PT (2008) The expression of microRNA miR-107 decreases early in Alzheimer's disease and may accelerate disease progression through regulation of beta-site amyloid precursor protein-cleaving enzyme 1. J Neurosci 28:1213-1223

192. Hebert SS, Horre K, Nicolai L, Papadopoulou AS, Mandemakers W, Silahtaroglu AN, Kauppinen S, Delacourte A, De Strooper B (2008) Loss of microRNA cluster miR-29a/b-1 in sporadic Alzheimer's disease correlates with increased BACE1/ beta-secretase expression. Proc Natl Acad Sci USA 105:64156420
193. Cogswell JP, Ward J, Taylor IA, Waters M, Shi Y, Cannon B, Kelnar K, Kemppainen J, Brown D, Chen C, Prinjha RK, Richardson JC, Saunders AM, Roses AD, Richards CA (2008) Identification of miRNA changes in Alzheimer's disease brain and CSF yields putative biomarkers and insights into disease pathways. J Alzheimers Dis 14:27-41

194. Boissonneault V, Plante I, Rivest S, Provost P (2009) MicroRNA-298 and microRNA-328 regulate expression of mouse betaamyloid precursor protein-converting enzyme 1. J Biol Chem 284:1971-1981

195. Kapsimali M, Kloosterman WP, de Bruijn E, Rosa F, Plasterk RH, Wilson SW (2007) MicroRNAs show a wide diversity of expression profiles in the developing and mature central nervous system. Genome Biol 8:R173

196. Mattick JS, Makunin IV (2005) Small regulatory RNAs in mammals. Hum Mol Genet 14(1):R121-R132

197. Lu J, Getz G, Miska EA, Alvarez-Saavedra E, Lamb J, Peck D, Sweet-Cordero A, Ebert BL, Mak RH, Ferrando AA, Downing JR, Jacks T, Horvitz HR, Golub TR (2005) MicroRNA expression profiles classify human cancers. Nature 435:834-838 